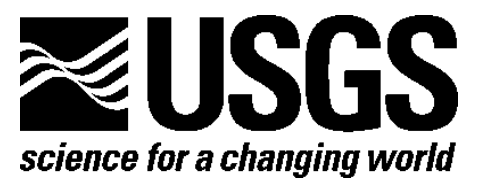

\title{
Toxicity, Sublethal Effects, and Potential Modes of Action of Select Fungicides on Freshwater Fish and Invertebrates
}

By Adria A. Elskus

Open-File Report 2012-1213

Version 1.1, November 2014

U.S. Department of the Interior

U.S. Geological Survey 


\section{U.S. Department of the Interior SALLY JEWELL, Secretary}

\section{U.S. Geological Survey \\ Suzette M. Kimball, Acting Director}

U.S. Geological Survey, Reston, Virginia, 2012

First release: 2012

Revised: November 2014 (ver 1.1)

For more information on the USGS—-the Federal source for science about the Earth,

its natural and living resources, natural hazards, and the environment-visit

http://www.usgs.gov or call 1-888-ASK-USGS

For an overview of USGS information products, including maps, imagery, and publications, visit http://www.usgs.gov/pubprod

To order this and other USGS information products, visit $h$ ttp://store.usgs.gov

Suggested citation:

Elskus, A.A., 2014, Toxicity, sublethal effects, and potential modes of action of select fungicides on freshwater fish and invertebrates (ver. 1.1, November 2014): U.S. Geological Survey Open-File Report 2012-1213, 42 p., http://dx.doi.org/10.3133/ofr20121213.

Any use of trade, firm, or product names is for descriptive purposes only and does not imply endorsement by the U.S. Government.

Although this information product, for the most part, is in the public domain, it also may contain copyrighted materials as noted in the text. Permission to reproduce copyrighted items must be secured from the copyright owner.

ISSN 2331-1258 (online) 


\section{Acknowledgments}

Critical reviews by Michael Focazio, Christopher Ingersoll, Kathryn Kuivila, and Kelly Smalling of the U.S. Geological Survey greatly improved the manuscript. Special thanks are extended to Lebelle Hicks, Maine Board of Pesticide Control, and to Emily Monosson for their exacting input on the focus, organization, and structure of this review. I thank Christy Finlayson for compiling the initial data for this report. Funding was provided by the Contaminants Biology Program and the Toxic Substances Hydrology Program of the U.S. Geological Survey. 


\section{Contents}

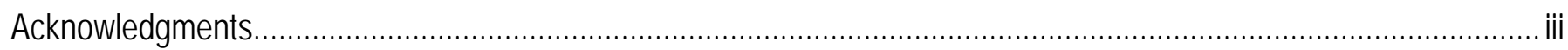

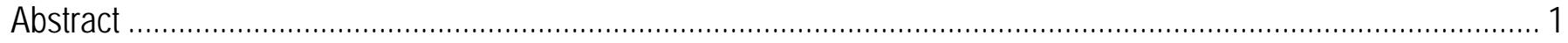

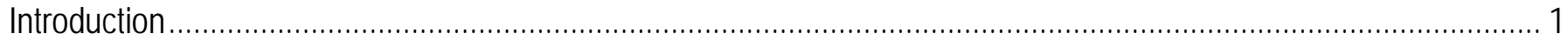

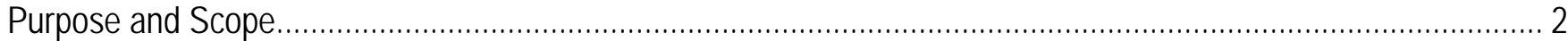

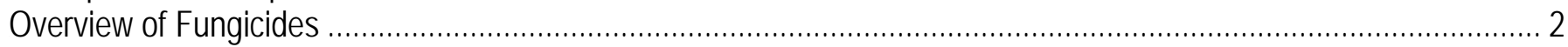

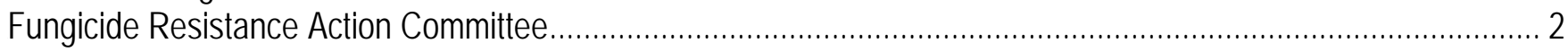

Fungicide Modes of Action .................................................................................................................... 3

Are Modes of Fungicide Action Related to Biochemical and Toxicological Effects in Fish and Invertebrates? .......... 3

Which Organisms, Life Stages, and Endpoints Are Most Sensitive? ............................................................ 12

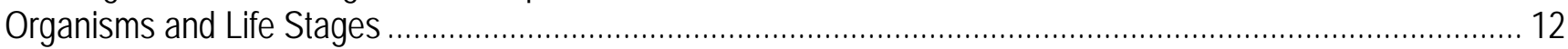

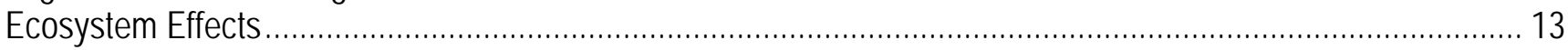



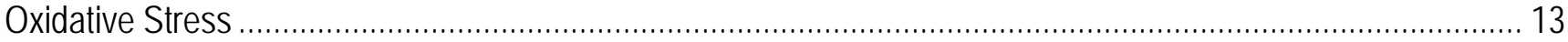

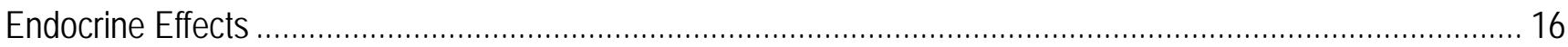

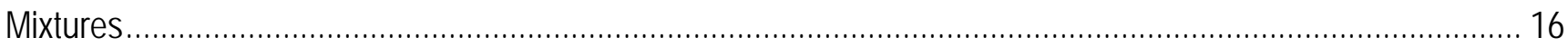

Detailed Summaries for Select Fungicides by Fungicide Resistance Action Committee Mode of Action .................... 16

Fungicide Resistance Action Committee Mode of Action B: Mitosis and Cell Division .......................................... 16

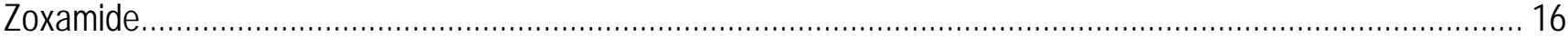

Environmental Fate in Aquatic Systems ………………

Mode of Toxic Action in Fungi................................................................................................... 17

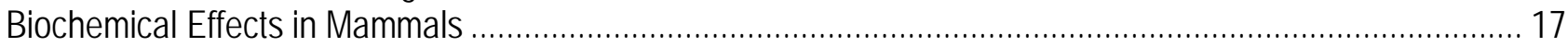

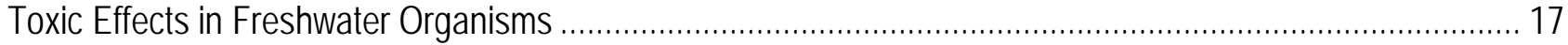

Relationship Between Zoxamide Fungal MOA and Effects in Nonfungal Organisms .................................. 17

Fungicide Resistance Action Committee Mode of Action C: Respiration ....................................................... 17

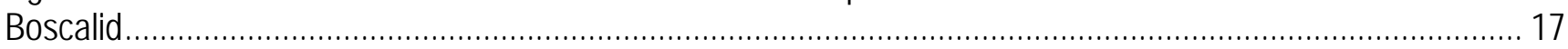

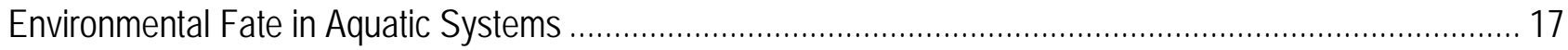

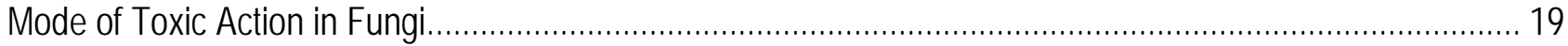

Biochemical Effects in Mammals ........................................................................................... 19

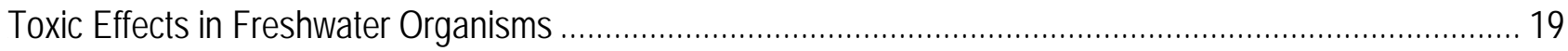

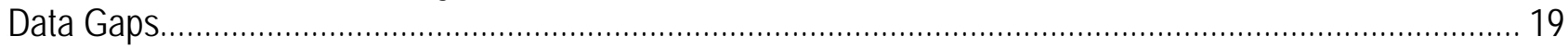

Relationship Between Boscalid Fungal MOA and Effects in Nonfungal Organisms...................................... 19

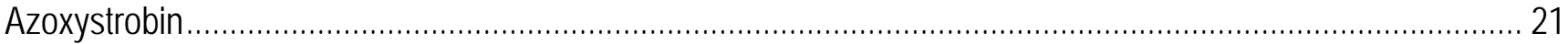

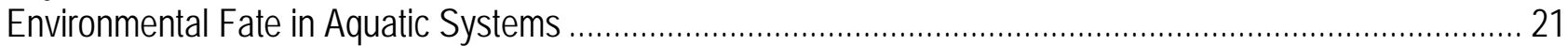

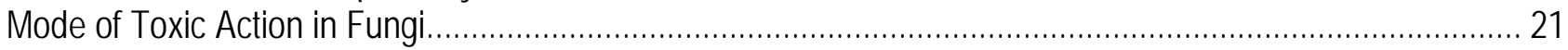



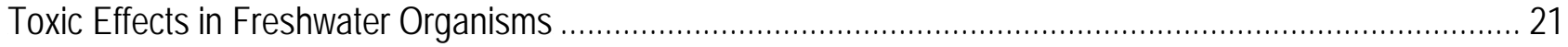

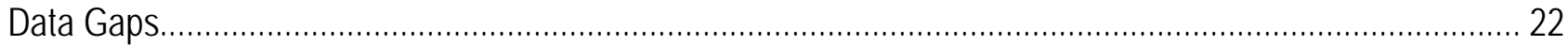

Relationship Between Azoxystrobin Fungal MOA and Effects in Nonfungal Organisms............................... 22

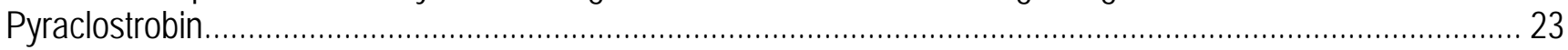



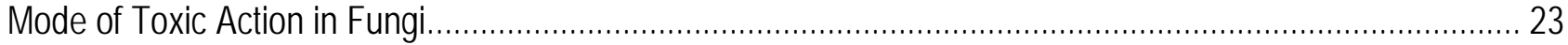

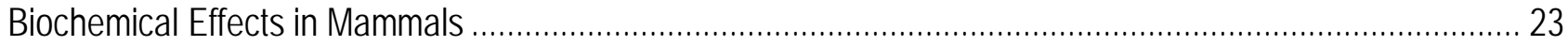

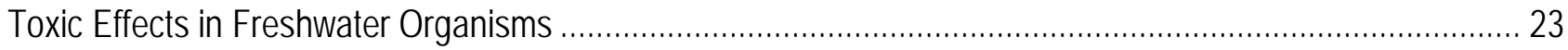

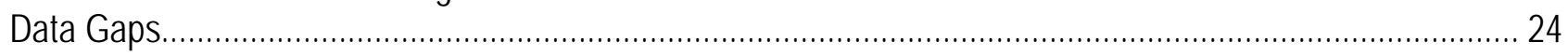


Relationship Between Fungicide MOA and Effects in Nonfungal Organisms ............................................ 24

Fungicide Resistance Action Committee Mode of Action D. Amino Acids and Protein Synthesis ........................... 24

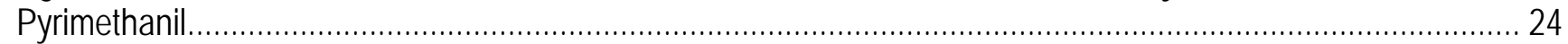

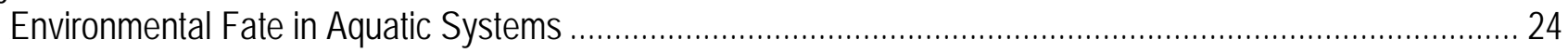

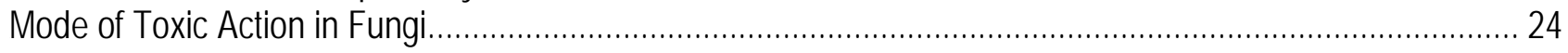

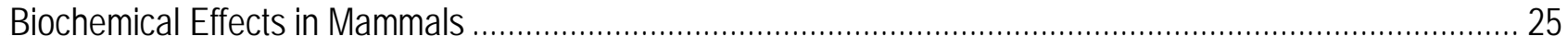

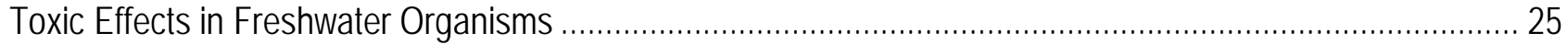

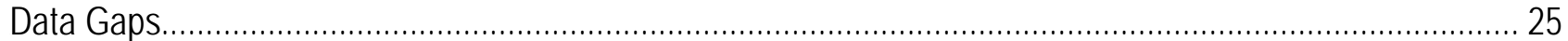

Relationship Between Fungicide MOA and Effects in Nonfungal Organisms ............................................ 25

Fungicide Resistance Action Committee Mode of Action E: Signal Transduction ............................................... 25

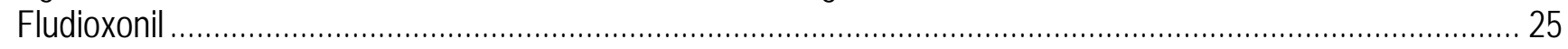

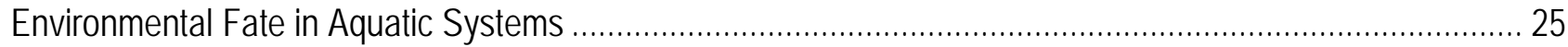

Mode of Toxic Action in Fungi............................................................................................... 26

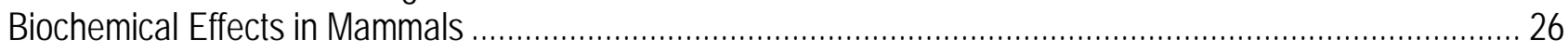

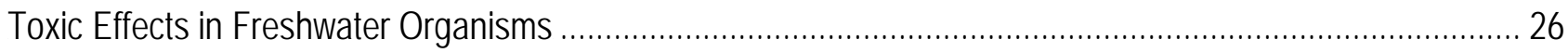

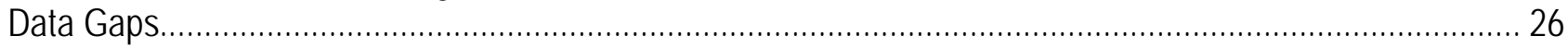

Relationship Between Fungicide MOA and Effects in Nonfungal Organisms ............................................ 26

Fungicide Resistance Action Committee Mode of Action G: Sterol Biosynthesis in Membranes ............................ 27

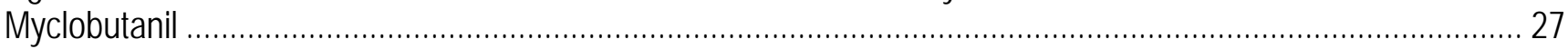

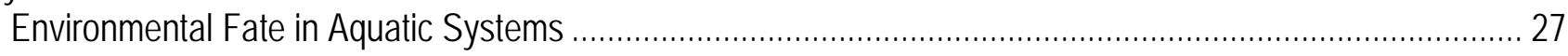

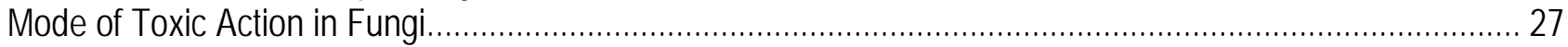



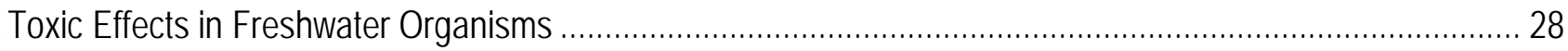

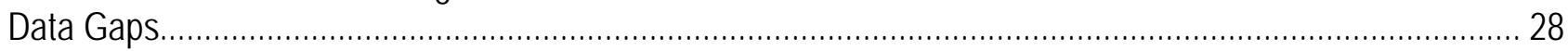

Relationship Between Fungicide MOA and Effects in Nonfungal Organisms ........................................... 28



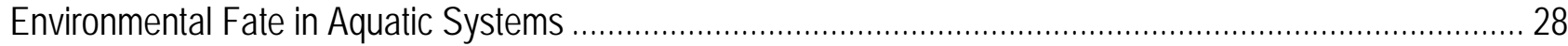



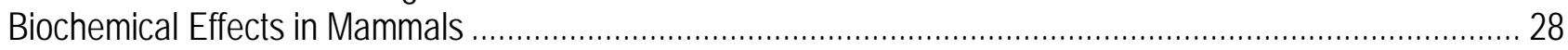

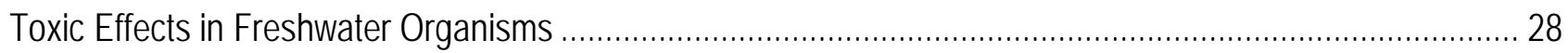

Relationship Between Fenarimol Fungal MOA and Effects in Nonfungal Organisms .................................. 29

Fungicide Resistance Action Committee Mode of Action: Multisite Contact Activity ............................................ 29

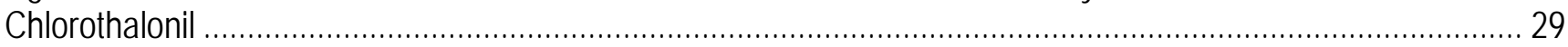

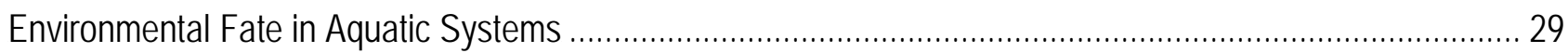

Mode of Toxic Action in Fungi................................................................................................... 30

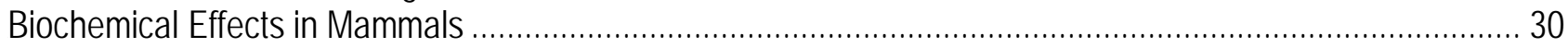

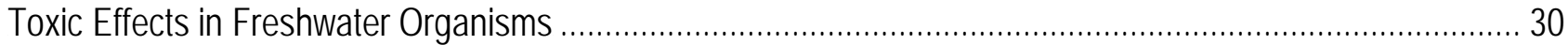

Relationship Between Chlorothalonil MOA and Effects in Nonfungal Organisms .......................................... 31



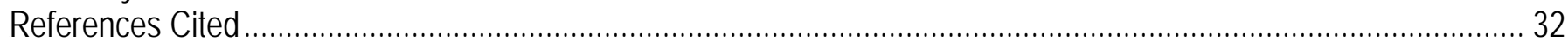

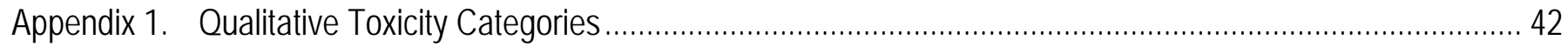

\section{Figure}

1. Graph depicting the relative toxic potency of a variety of fungicides to Daphnia magna ................................ 14 


\section{Tables}

1. FRAC mode of action (MOA) and structure for fungicides in this review. ............................................... 4

2. Fungicide MOA target site in fungi and biochemical effects in mammals and aquatic organisms. .................. 6

3. Physiological effects of select fungicides in mammals and aquatic organisms ......................................... 9

4. Lowest reported lethal (EC50, LC50) and NOEC/NOAEC values for aquatic organisms. .............................. 15

5. Physical-chemical properties and bioconcentration factors (BCF) for selected fungicides. ............................ 18

6. Aquatic life benchmarks and toxicity category for select fungicides....................................................... 20

1-1. Qualitative toxicity categories for fish and aquatic invertebrates......................................................... 422

\section{Abbreviations}

a.i.

AhR

Aldh1a1

AR

ATP

b.w.

cgs

CYP19

CYP1A

CYP1A1

Cyp1a1

CYP1A2

CYP2B1/2

Сур2b2

CYP2E1

Сурза1

CYP3A1/2

Сур3а2

CYP450

Cyp4a10

Cyp51

CYP51

cyt b

cyto bc1

$\mathrm{kg}$

d

DMI

DNA

DT50

DT90

EBDC

EBI

EC50

EDC

EPA

ER

erg11

ERa

GST

HOG1

IGFB1

Koc

Kow active ingredient

Aryl hydrocarbon receptor

aldehyde dehydrogenase

Androgen receptor

adenosine triphosphate

body weight

cystathionine gamma-synthase gene

cytochrome P450 19 protein (aromatase)

cytochrome P450 1A protein

cytochrome P450 1A1 protein

cytochrome P4501A1 gene

cytochrome P450 1A2 protein

cytochrome $\mathrm{P} 4502 \mathrm{~B} 1 / 2$ protein

cytochrome P4501B2 gene

cytochrome P450 2E1 protein

cytochrome P4503A1 gene

cytochrome $\mathrm{P} 4503 \mathrm{~A} 1 / 2$ protein

cytochrome P4503A2 gene

cytochrome P450

cytochrome P4504A10 gene

cytochrome P450 51 gene

cytochrome P450 51 protein

cytochrome $b$

cytochrome bc1 (ubiquinol oxidase)

kilogram

day

cytochrome P450-demethylase inhibiting

deoxyribonucleic acid

length of time needed for 50 percent of the chemical to disappear relative to its initial

length of time needed for 90 percent of the chemical to disappear relative to its initial

concentration

ethylene bisdithio-carbamate

ergosterol biosynthesis inhibiting

concentration that effects a response in 50 percent of the organisms

endocrine disrupting compound

U.S. Environmental Protection Agency

estrogen receptor

ergosterol biosynthesis gene (lanosterol 14-a-demethylase)

estrogen receptor a

glutathione S-transferase

a mitogen-activated kinase

insulin-like growth factor 1

organic carbon-water partition coefficient

octanol-water partition coefficient concentration 


$\begin{array}{ll}\text { LC50 } & \text { concentration that is lethal to } 50 \text { percent of the organisms } \\ \text { LOEC } & \text { lowest observed effects concentration } \\ \text { M } & \text { molar concentration } \\ \text { MAP } & \text { mitogen-activated protein } \\ \text { MAP3K7 } & \text { mitogen-activated protein kinase kinase kinase } 7 \\ \text { MAPK1 } & \text { mitogen-activated protein kinase 1 } \\ \text { MOA } & \text { mode of action } \\ \text { NADPH } & \text { nicotinamide adenine dinucleotide phosphate (reduced form) } \\ \text { NOAEC } & \text { no observed adverse effects concentration } \\ \text { NOEC } & \text { no observed effects concentration } \\ \text { NOEL } & \text { no observed effects } \\ \text { os-2 } & \text { osmosensitive-2 gene } \\ \text { PCX } & \text { pyruvate carboxylase } \\ \text { Ppap2b } & \text { phosphatidic acid phosphatase 2B } \\ \text { Q0 } & \text { quinol oxidation site of the mitochrondrial cytochrome bc1 complex } \\ \text { RNA } & \text { ribonucelic acid } \\ \text { ROS } & \text { reactive oxygen species } \\ \text { Slco1a4 } & \text { solute carrier family transporter gene } \\ \text { SSD } & \text { species sensitivity distribution } \\ \text { T4 } & \text { thyroxine } \\ \text { TNFR } & \text { tumor necrosis factor receptor } \\ \text { TSH } & \text { thryoid stimulating hormone } \\ \text { UDPGT } & \text { uridine diphosphate glycuronyltransferase } \\ \text { Udpgtr2 } & \text { uridine-diphophaste glucuronosyl transferase 2 gene } \\ \text { Ugt1a1 } & \text { uridine glucuonosyl transferase 1A1 gene } \\ \text { Ugt2a1 } & \text { uridine glucuonosyl transferase 2A1 gene } \\ \text { USGS } & \text { U.S. Geological Survey } \\ & \end{array}$





\title{
Toxicity, Sublethal Effects, and Potential Modes of Action of Select Fungicides on Freshwater Fish and Invertebrates
}

\author{
By Adria A. Elskus
}

\begin{abstract}
Despite decades of agricultural and urban use of fungicides and widespread detection of these pesticides in surface waters, relatively few data are available on the effects of fungicides on fish and invertebrates in the aquatic environment. Nine fungicides are reviewed in this report: azoxystrobin, boscalid, chlorothalonil, fludioxonil, myclobutanil, fenarimol, pyraclostrobin, pyrimethanil, and zoxamide. These fungicides were identified as emerging chemicals of concern because of their high or increasing global use rates, detection frequency in surface waters, or likely persistence in the environment. A review of the literature revealed significant sublethal effects of fungicides on fish, aquatic invertebrates, and ecosystems, including zooplankton and fish reproduction, fish immune function, zooplankton community composition, metabolic enzymes, and ecosystem processes, such as leaf decomposition in streams, among other biological effects. Some of these effects can occur at fungicide concentrations well below single-species acute lethality values (48- or 96-hour concentration that effects a response in 50 percent of the organisms, that is, effective concentration killing 50 percent of the organisms in 48 or 96 hours) and chronic sublethal values (for example, 21-day no observed adverse effects concentration), indicating that single-species toxicity values may dramatically underestimate the toxic potency of some fungicides. Fungicide modes of toxic action in fungi can sometimes reflect the biochemical and (or) physiological effects of fungicides observed in vertebrates and invertebrates; however, far more studies are needed to explore the potential to predict effects in nontarget organisms based on specific fungicide modes of toxic action. Fungicides can also have additive and (or) synergistic effects when used with other fungicides and insecticides, highlighting the need to study pesticide mixtures that occur in surface waters. For fungicides that partition to organic matter in sediment and soils, it is particularly important to determine their effects on freshwater mussels and other freshwater benthic invertebrates in contact with sediments, as available toxicity studies with pelagic species, mainly Daphnia magna, may not be representative of these benthic organisms. Finally, there is a critical need for studies of the chronic effects of fungicides on reproduction, immunocompetence, and ecosystem function; sublethal endpoints with population and community-level relevance.
\end{abstract}

\section{Introduction}

With use rates projected to rise dramatically in the next few years (Troy, 2011), fungicides are one of the emerging chemical classes of concern in freshwater systems in the United States. Unlike herbicides, which have received much attention due to their putative effects at low concentrations with vertebrates (for example, atrazine) (Hayes and others, 2002), and unlike insecticides, whose effects on nontarget invertebrates and vertebrates have been widely recognized for decades (Carson, 1964; Gustafsson and others, 2010), there have been few studies of fungicide biochemical and physiological 
effects on nonfungal organisms (Relyea and Hoverman, 2006; Warming and others, 2009). The nine fungicides in this review were selected based on their high or increasing use, detection frequency, or likely persistence: azoxystrobin, boscalid, chlorothalonil, fludioxonil, myclobutanil, fenarimol, pyraclostrobin, pyrimethanil, and zoxamide. Focused surveys conducted by the U.S. Geological Survey (USGS) found that these fungicides are transported off-site from a variety of use-setting and into aquatic habitats where they may impact sensitive communities. However, data on occurrence remain scarce (Gilliom and others, 2006). For the fungicides in this review for which data are available, maximum surface-water concentrations have been reported of 4.6 micrograms per liter $(\mu \mathrm{g} / \mathrm{L})$ for azoxystrobin (Smalling and Orlando, 2011), $36 \mu \mathrm{g} / \mathrm{L}$ for boscalid (Smalling and Orlando, 2011), 0.433 $\mu \mathrm{g} / \mathrm{L}$ for chlorothalonil (Scribner and others, 2006; Smalling and Orlando, 2011), $2.6 \mu \mathrm{g} / \mathrm{L}$ for myclobutanil (Smalling and Orlando, 2011), and 7.1 $\mu \mathrm{g} / \mathrm{L}$ for pyraclostrobin (Smalling and Orlando, 2011).

As for all pesticides, fungicides undergo a registration process overseen by the U.S. Environmental Protection Agency (EPA). Pesticide registration is the process through which the EPA examines the ingredients of a pesticide; the site or crop on which it is to be used; the amount, frequency, and timing of its use; and storage and disposal practices. The EPA evaluates the pesticide to ensure that it will not have unreasonable adverse effects on humans, the environment, and nontarget species (U.S. Environmental Protection Agency, 2012b, p. 756).

The data in this review are derived from the EPA and Canadian pesticide registration documents and Web sites, the Pesticide Properties Database (University of Hertfordshire), the Fungicide Resistance Action Committee Web site, and from primary literature identified through Web of Science, and include standard toxicity test species, as well as a variety of nonstandard organisms.

\section{Purpose and Scope}

Data on the sublethal effects of fungicides in nonfungal organisms, particularly vertebrates and invertebrates, are scarce. The purpose of this report is to provide information on the toxic effects to fish and aquatic invertebrates of nine fungicides (azoxystrobin, boscalid, chlorothalonil, fludioxonil, myclobutanil, fenarimol, pyraclostrobin, pyrimethanil, and zoxamide). Theses fungicides were identified as emerging chemicals of concern because of their high or increasing global-use rates, detection frequency in surface waters, or likely persistence in the environment. The report provides an overview of fungicide modes of action; the relationship of these modes of action to acute toxicity in nonfungal organisms; and the relative sensitivity of different aquatic species, life stages, and endpoints. The bulk of the report consists of summaries for each selected fungicide: (1) physical and chemical characteristics as related to environmental fate in aquatic systems; (2) mode of toxic action in fungi; (3) biochemical and physiological effects in mammals, fish, and aquatic invertebrates (where known); (4) the potential of fungal modes of action to predict effects in vertebrates and invertebrates; and (5) data gaps related to toxicity testing.

\section{Overview of Fungicides}

\section{Fungicide Resistance Action Committee}

The development of fungal resistance to fungicides is a continuous and costly problem, leading to loss of crops, increased prices for food, and food shortages. The Fungicide Resistance Action Committee (FRAC) is a specialist technical group of CropLife International whose purpose is to

"provide fungicide resistance management guidelines to prolong the effectiveness of 'at risk’ fungicides and to limit crop losses should resistance occur” (Fungicide Resistance Action Committee, 2012). 
The FRAC provides a list of fungicides, the FRAC code list, sorted by mode of action and resistance risk, which is updated annually to include new and reclassified fungicides.

\section{Fungicide Modes of Action}

Fungicides are classified according to their biochemical mode of action in fungal organisms (Fungicide Resistance Action Committee, 2012). Fungicides target basic cellular processes, with many inhibiting fungal biosynthesis of sterols or tubulin or cytochrome-c reductase activity (Casida, 2009). Most fungicides target single biochemical sites, but a few have multiple targets. The 10 general categories are: mitosis and cell division, nucleic acids synthesis, respiration, amino acids and protein synthesis, signal transduction, lipids and membrane synthesis, sterol biosynthesis in membranes, glucan synthesis, melanin synthesis in cell wall, and host plant defense induction. The 11th mode is multi-site contact activity and the 12th classification is for those compounds with fungicidal activity and an unknown mode of action. Even for fungicides whose mode of action is known, often only the general mechanism has been identified (for example, inhibition of mitochondrial respiration, inhibition of ribosomal RNA synthesis, nonsystemic/protectant barriers, and nonspecific enzyme inactivation), while the specific target site(s) remain uncertain. As fungi often develop resistance to these toxins, new fungicides are continuously being introduced to the environment. Multi-site contact fungicides (for example, chlorothalonil) typically remain effective longer than single-site fungicides (Brent and Hollomon, 2007); however, single-site fungicides, by attacking specific biochemical targets, may have fewer side effects on other biochemical processes or nontarget organisms (Gisi and Sierotzki, 2008).

In contrast to the target organism (fungi), almost nothing is known regarding fungicide toxic mechanisms in nontarget organisms. Similarly, while effects on some biochemical pathways have been described in mammals and fish, little is known about biochemical pathways affected in invertebrates. Using a battery of in vitro, high-throughput screening assays, ToxCast, an EPA program, has demonstrated that any given environmental chemical, including fungicides, can perturb numerous biochemical pathways in mammals (Judson and others, 2010).

The site-specific fungicides in this review (table 1) include those that inhibit fungal mitosis and cell division (zoxamide), respiration (azoxystrobin, pyraclostrobin, boscalid), amino acid and protein synthesis (pyrimthanil), signal transduction (fludioxonil), and sterol biosynthesis in membranes (myclobutanil, fenarimol); there is one multisite contact fungicide included (chlorothalonil).

\section{Are Modes of Fungicide Action Related to Biochemical and Toxicological Effects in Fish and Invertebrates?}

As many biochemical pathways and processes are conserved across species, modes of fungicide action could predict analogous mechanisms of toxicity, target site(s), and (or) toxic effects for nonfungal species. A comparison of fungicide modes of action (MOAs) with biochemical and physiological effects in vertebrates and invertebrates indicates that fungicides may be targeting the same or related biochemical and (or) physiological processes in nonfungal species (tables 2 and 3). Several researchers provide evidence supporting this view. Ochoa-Acuna and colleagues (2009) suggest that the adverse effects of conazole fungicides in nontarget species may be mediated through cytochrome P450 pathways common across species. Strong evidence in support of such expectations is provided by Mazur and Kenneke (2008) who report similar, and in some cases identical, in vitro metabolite profiles for conazoles in trout, rat, and human liver. Other examples are provided by chlorothalonil, which exerts its toxic effects on fungi by complexing with sulphydryl-containing proteins, leading to depletion of glutathione reserves (Arvanites and Boerth, 2001); some of these same thiol-reactive processes are affected in fish (Davies, 1985b; Gallagher and others, 1992; Davies and others, 1994) and invertebrates 
(Davies and others, 1994; Baier-Anderson and Anderson, 1998, 2000a). Azoxystrobin affects respiration in fungi by inhibiting electron transport in mitochondria, leading to cellular oxidative stressand disruption of fungal metabolism and growth. Recent studies indicate that azoxystrobin disrupts mitochondrial respiration in both fungi (Bartlett and others, 2002; Kim and others, 2007; Gisi and Sierotzki, 2008) and fish (Olsvik and others, 2010). Imidazoles, triazoles, and the pyrimidine fungicide fenarimol belong to the cytochrome P450-de-methylase inhibiting (DMI) class of fungicides, but disrupt other CYP450s, such as aromatase (CYP19) in both mammals and fish, indicating endocrine disruptive action is associated with DMI fungicides (Ankley and others, 2005; Hinfray and others, 2006; Sisman and Turkez, 2010). While such biochemical insights do not allow cross-species predictions of toxic potency, they do provide a first step towards identifying potential MOAs in aquatic invertebrates and fish for which mechanistic studies of fungicide action have not been conducted.

Table 1. FRAC mode of action (MOA) and structure for fungicides in this review.

[MOA, mode of action; FRAC, Fungicide Resistance Action Committee; CAS No., Chemical Abstracts Service registry number; see Abbreviations for protein and gene definitions]

\begin{tabular}{|c|c|c|c|c|}
\hline $\begin{array}{l}\text { FRAC MOA code and } \\
\text { target site }\end{array}$ & Fungicide & CAS no. & Chemical group & Structure \\
\hline
\end{tabular}

B. mitosis and cell
division
B3: $\alpha$-tubulin
assembly in mitosis

C. respiration
C2: complex II -
succinate
dehydrogenase

C3: complex III - cyto bc1 (ubiquinol oxidase) at Qo site (cyt b gene)

C3: complex III - cyto bc1 (ubiquinol oxidase) at Qo site (cyt b gene)

D. amino acids and
protein synthesis
D1: methionine
biosynthesis
(proposed)

$\begin{array}{lcc}\text { Zoxamide } & \text { 156052-68-5 } & \text { Toluamide } \\ \text { Boscalid } & 188425-85-6 & \text { Pyridine-carboxamide }\end{array}$

Azoxystrobin 131860-33-8 Methoxy-acrylate

(1)

Pyraclostrobin 175013-18-0 Methoxy-carbamate

Pyrimethanil 53112-28-0 Anilino-pyrimidine
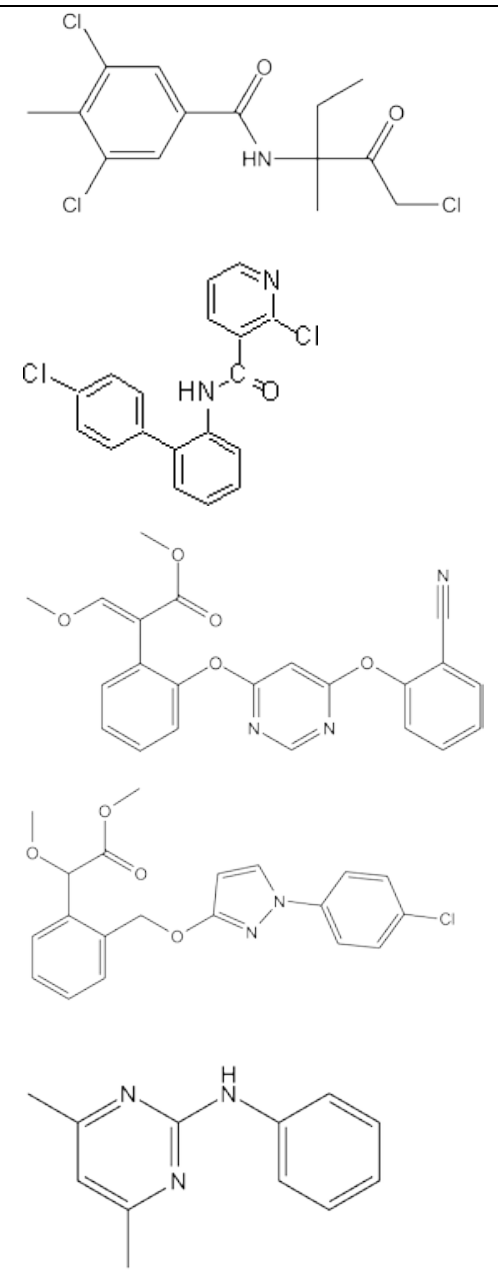
Table 1. FRAC mode of action (MOA) and structure for fungicides in this review.-Continued

[MOA, mode of action; FRAC, Fungicide Resistance Action Committee; CAS No., Chemical Abstracts Service registry number; see Abbreviations for protein and gene definitions]

\begin{tabular}{|c|c|c|c|c|}
\hline $\begin{array}{l}\text { FRAC MOA code and } \\
\text { target site }\end{array}$ & Fungicide & CAS no. & Chemical group & Structure \\
\hline $\begin{array}{l}\text { E. signal } \\
\text { transduction } \\
\text { E2: MAP/histidine- } \\
\text { kinase in osmotic } \\
\text { signal tranduction }\end{array}$ & Fludioxonil & 131341-86-1 & Phenylpyrrole & \\
\hline $\begin{array}{l}\text { G. sterol biosynthesis } \\
\text { in membranes } \\
\text { G1: C14-demethylase } \\
\text { in sterol biosynthesis } \\
\text { (erg11/cyp51) }\end{array}$ & Myclobutanil & 88671-89-0 & Triazole & \\
\hline $\begin{array}{l}\text { G1: C14-demethylase } \\
\text { in sterol biosynthesis } \\
\text { (erg11/cyp51) }\end{array}$ & Fenarimol & 60168-88-9 & Pyrimidine & \\
\hline $\begin{array}{l}\text { Multi-site contact } \\
\text { activity }\end{array}$ & Chlorothalonil & 37223-69-1 & $\begin{array}{l}\text { Chloronitrile } \\
\text { (phthalonitrile) }\end{array}$ & \\
\hline
\end{tabular}


Table 2. Fungicide MOA target site in fungi and biochemical effects in mammals and aquatic organisms.

[MOA, mode of action; FRAC, Fungicide Resistance Action Committee; NA, no information is available; see List of Abbreviations for protein and gene definitions]

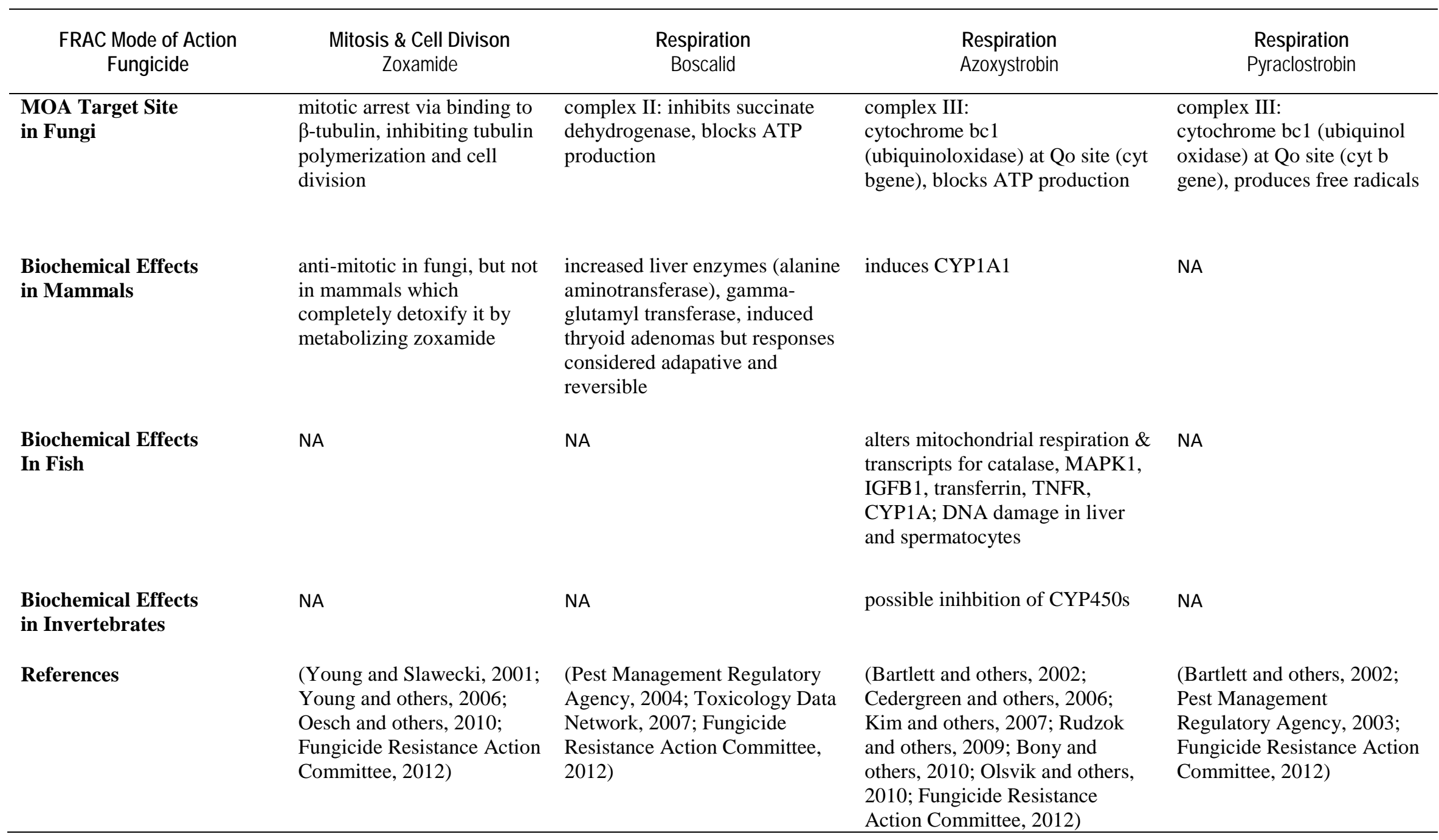


Table 2. Fungicide MOA target site in fungi and biochemical effects in mammals and aquatic organisms-Continued

[MOA, mode of action; FRAC, Fungicide Resistance Action Committee; NA, no information is available; see List of Abbreviations for protein and gene definitions]

\begin{tabular}{|c|c|c|c|c|}
\hline $\begin{array}{l}\text { FRAC Mode of Action } \\
\text { Fungicide }\end{array}$ & $\begin{array}{c}\text { Amino Acid \& Protein } \\
\text { Synthesis } \\
\text { Pyrimethanil } \\
\end{array}$ & $\begin{array}{l}\text { Signal Transduction } \\
\text { Fludioxonil }\end{array}$ & $\begin{array}{c}\text { Sterol Biosynthesis in } \\
\text { Membranes } \\
\text { Myclobutanil }\end{array}$ & $\begin{array}{c}\text { Sterol Biosynthesis in } \\
\text { Membranes } \\
\text { Fenarimol }\end{array}$ \\
\hline $\begin{array}{l}\text { MOA Target Site } \\
\text { in Fungi }\end{array}$ & $\begin{array}{l}\text { disrupts methionine } \\
\text { biosynthesis (cgs gene) } \\
\text { inihibiting secretion of } \\
\text { membrane-degrading } \\
\text { enzymes }\end{array}$ & $\begin{array}{l}\text { MAP/Histidine-Kinase in } \\
\text { osmotic signaltransduction (os- } \\
\text { 2, HOG1), alters } \\
\text { osmoregulation }\end{array}$ & $\begin{array}{l}\text { C14- demethylase in sterol } \\
\text { biosynthesis (erg11/cyp51) }\end{array}$ & $\begin{array}{l}\text { C14- demethylase in sterol } \\
\text { biosynthesis (erg11/cyp51) }\end{array}$ \\
\hline $\begin{array}{l}\text { Biochemical Effects } \\
\text { in Mammals }\end{array}$ & $\begin{array}{l}\text { enhances the hepatic } \\
\text { metabolism and excretion of } \\
\text { thyroid hormone, increases } \\
\text { CYP450s \& UDPGT }\end{array}$ & NA & $\begin{array}{l}\text { perturbed fatty acid, steroid, } \\
\text { and xenobiotic metabolism } \\
\text { pathways, binds ER } \alpha \text { (estrogen } \\
\text { receptor), reduced retinoic acid, } \\
\text { induced oxidative stress genes }\end{array}$ & $\begin{array}{l}\text { endocrine agonist/antagonist } \\
\text { (ER,AR, inhibits CYP19 } \\
\text { aromatase), alters activity of } \\
\text { several CYP450 enzymes }\end{array}$ \\
\hline $\begin{array}{l}\text { Biochemical Effects } \\
\text { in Fish }\end{array}$ & NA & NA & NA & $\begin{array}{l}\text { endocrine disruptor (binds AR, } \\
\text { inhibits CYP19, altered plasma } \\
\text { steroids, vitellogenin, steroid } \\
\text { glucuronidation), carbonic } \\
\text { anhydrase }\end{array}$ \\
\hline $\begin{array}{l}\text { Biochemical Effects } \\
\text { in Invertebrates }\end{array}$ & NA & NA & NA & $\begin{array}{l}\text { Endocrine disruptive effects, } \\
\text { but no biochemical mechanism } \\
\text { determined }\end{array}$ \\
\hline References & $\begin{array}{l}\text { (Milling and Richardson, } \\
\text { 1995; Fritz and others, } \\
\text { 1997; Hurley and others, } \\
\text { 1998; New York State } \\
\text { Department of } \\
\text { Environmental } \\
\text { Conservation, 2005; } \\
\text { Fungicide Resistance Action } \\
\text { Committee, 2012) }\end{array}$ & $\begin{array}{l}\text { (Motoyama and others, 2005; } \\
\text { Vetcher and others, 2007; } \\
\text { Kanetis and others, 2008; U.S. } \\
\text { Environmental Protection } \\
\text { Agency, 2011c; Fungicide } \\
\text { Resistance Action Committee, } \\
\text { 2012) }\end{array}$ & $\begin{array}{l}\text { (Okubo and others, 2004; Duft } \\
\text { and others, 2007; Sun and } \\
\text { others, 2007; Goetz and Dix, } \\
\text { 2009; Hata and others, 2010; } \\
\text { Fungicide Resistance Action } \\
\text { Committee, 2012; Pesticide } \\
\text { Properties Database, 2012), } \\
\text { studies cited in Chen and } \\
\text { others, } 2009\end{array}$ & $\begin{array}{l}\text { (Andersen and others, 2002; } \\
\text { Griffiths and Howlett, 2002; } \\
\text { Isik and others, 2004; Thibaut } \\
\text { and Porte, 2004; Ankley and } \\
\text { others, 2005; Janer and others, } \\
\text { 2005; Hinfray and others, 2006; } \\
\text { Serap, 2006; Canistro and } \\
\text { others, 2008; Hassold and } \\
\text { Backhaus, 2009; Fungicide } \\
\text { Resistance Action Committee, } \\
\text { 2012) }\end{array}$ \\
\hline
\end{tabular}


Table 2. Fungicide MOA target site in fungi and biochemical effects in mammals and aquatic organisms.-Continued

[MOA, mode of action; FRAC, Fungicide Resistance Action Committee; NA, no information is available; see Abbreviations for protein and gene definitions]

\begin{tabular}{ll}
\hline \multicolumn{1}{c}{$\begin{array}{c}\text { FRAC Mode of Action } \\
\text { Fungicide }\end{array}$} & \multicolumn{1}{c}{$\begin{array}{c}\text { Multi-site Contact Activity } \\
\text { Chlorothalonil }\end{array}$} \\
\hline $\begin{array}{l}\text { MOA Target Site } \\
\text { in Fungi }\end{array}$ & $\begin{array}{l}\text { depletes glutathione, inhibits NADPH oxidase \& } \\
\text { glyceraldehyde 3-phosphate dehydrogenase } \\
\text { (glycolysis) }\end{array}$ \\
$\begin{array}{l}\text { Biochemical Effects } \\
\text { in Mammals }\end{array}$ & $\begin{array}{l}\text { aryl-hydrocarbon receptor (AhR) agonist; induced } \\
\text { lipid peroxidation; binds glutathione }\end{array}$ \\
& \\
Biochemical Effects & \\
in Fish & affected immune responses (reduced/increased \\
& ROS, phagocytic activity, NADPH oxidase); \\
altered levels of gluththione, GST, thiol, RNA \& & DNA \\
Biochemical Effects & may affect immune function, induced glutathione, \\
in Invertebrates & suppressed ROS production, may inhibit the \\
& activation of NADPH oxidase-like enzyme \\
References & (Davies, 1985; Gallagher and others, 1992; Davies \\
and others, 1994; Baier-Anderson and Anderson, \\
1998, 2000a, 2000b; U.S. Environmental \\
Protection Agency, 1999; Long and others, 2003; \\
Suzuki and others, 2004; Shelley and others, 2009; \\
McMahon and others, 2011; Zhao and others, \\
2011; Fungicide Resistance Action Committee, \\
2012)
\end{tabular}


Table 3. Physiological effects of select fungicides in mammals and aquatic organisms.

[NA, no information is available; FRAC, Fungicide Resistance Action Committee; see List of Abbreviations for protein and gene definitions; see text for references]

\begin{tabular}{|c|c|c|c|c|}
\hline $\begin{array}{l}\text { FRAC Mode of Action } \\
\text { Fungicide }\end{array}$ & $\begin{array}{l}\text { Mitosis \& Cell Division } \\
\text { Zoxamide }\end{array}$ & $\begin{array}{l}\text { Respiration } \\
\text { Boscalid }\end{array}$ & $\begin{array}{l}\text { Respiration } \\
\text { Azoxystrobin }\end{array}$ & $\begin{array}{l}\text { Respiration } \\
\text { Pyraclostrobin }\end{array}$ \\
\hline $\begin{array}{l}\text { Physiological Effects } \\
\text { in Mammals }\end{array}$ & $\begin{array}{l}\text { not mutagenic, mammals } \\
\text { detoxify mitosis- } \\
\text { inhibiting properties }\end{array}$ & $\begin{array}{l}\text { not genotoxic, neurotoxic, } \\
\text { teratogenic or a reproductive } \\
\text { toxin }\end{array}$ & $\begin{array}{l}\text { liver and bile duct pathology, not } \\
\text { a genotoxic, neurotoxic, } \\
\text { mutagenic, teratogenic or a } \\
\text { reproductive toxin }\end{array}$ & $\begin{array}{l}\text { thymic atrophy \& apoptosis of } \\
\text { lymph nodes under acute, but not } \\
\text { chronic, exposure }\end{array}$ \\
\hline $\begin{array}{l}\text { Physiological Effects } \\
\text { in Fish }\end{array}$ & NA & lethargy and narcosis & $\begin{array}{l}\text { altered biochemical parameters } \\
\text { associated with mitochondrial } \\
\text { respiration, oxidative stress, cell } \\
\text { proliferation; provoked DNA } \\
\text { damage in liver and } \\
\text { spermatocytes }\end{array}$ & NA \\
\hline $\begin{array}{l}\text { Physiological Effects } \\
\text { in Aquatic } \\
\text { Invertebrates }\end{array}$ & NA & $\begin{array}{l}\text { reduced daphnid fecundity, } \\
\text { reduced Chironomid } \\
\text { emergence }\end{array}$ & $\begin{array}{l}\text { altered zooplankton community } \\
\text { structure, daphnid swimming, } \\
\text { fecundity, respiration, heart rate; } \\
\text { no effect on downstream drift }\end{array}$ & $\begin{array}{l}\text { highly toxic to freshwater mussel } \\
\text { glochidia and juveniles }\end{array}$ \\
\hline $\begin{array}{l}\text { Physiological Effects } \\
\text { in Amphibians }\end{array}$ & NA & NA & $\begin{array}{l}\text { little to no effect on survival, } \\
\text { fecundity, metamorphosis, growth }\end{array}$ & NA \\
\hline
\end{tabular}


Table 3. Physiological effects of select fungicides in mammals and aquatic organisms.-Continued

[NA, no information is available; FRAC, Fungicide Resistance Action Committee; see List of Abbreviations for protein and gene definitions; see text for references]

\begin{tabular}{|c|c|c|c|c|}
\hline $\begin{array}{l}\text { FRAC Mode of Action } \\
\text { Fungicide }\end{array}$ & $\begin{array}{l}\text { Amino Acid \& Protein } \\
\text { Synthesis } \\
\text { Pyrimethanil }\end{array}$ & $\begin{array}{l}\text { Signal Transduction } \\
\text { Fludioxonil }\end{array}$ & $\begin{array}{l}\text { Sterol Biosynthesis in Membranes } \\
\text { Myclobutanil }\end{array}$ & $\begin{array}{c}\text { Sterol Biosynthesis in Membranes } \\
\text { Fenarimol }\end{array}$ \\
\hline $\begin{array}{l}\text { Physiological Effects } \\
\text { in Mammals }\end{array}$ & $\begin{array}{l}\text { enhanced thyroid } \\
\text { hormone metabolism \& } \\
\text { excretion, thyroid } \\
\text { hyperplasia, } \\
\text { hypertrophy, decreased } \\
\text { T4, increased TSH, } \\
\text { increased biliary flow, } \\
\text { possible carcinogen }\end{array}$ & $\begin{array}{l}\text { not genotoxic, teratogenic, or } \\
\text { carcinogenic }\end{array}$ & $\begin{array}{l}\text { binds estrogen receptor, perturbs } \\
\text { steroid, fatty acid \& xenobiotic } \\
\text { metaboism, reduced liver retinoic } \\
\text { acid }\end{array}$ & endocrine disruption \\
\hline $\begin{array}{l}\text { Physiological Effects } \\
\text { in Fish }\end{array}$ & NA & NA & $\begin{array}{l}\text { quiescence, loss of equilibrium, } \\
\text { surfacing, dark coloration }\end{array}$ & $\begin{array}{l}\text { endocrine disruption, reduced } \\
\text { fecundity }\end{array}$ \\
\hline $\begin{array}{l}\text { Physiological Effects } \\
\text { in Aquatic } \\
\text { Invertebrates }\end{array}$ & NA & NA & induced settling to bottom & $\begin{array}{l}\text { endocrine disruptor, imposex in } \\
\text { snails, reduced egg production, } \\
\text { delayed molting, developmental } \\
\text { deformities }\end{array}$ \\
\hline $\begin{array}{l}\text { Physiological Effects } \\
\text { in Amphibians }\end{array}$ & NA & NA & NA & NA \\
\hline
\end{tabular}


Table 3. Physiological effects of select fungicides in mammals and aquatic organisms.-Continued

[NA, no information is available; FRAC, Fungicide Resistance Action Committee; see List of Abbreviations for protein and gene definitions; see text for references]

\begin{tabular}{|c|c|}
\hline $\begin{array}{l}\text { FRAC Mode of Action } \\
\text { Fungicide }\end{array}$ & $\begin{array}{c}\text { Multi-site Contact Activity } \\
\text { Chlorothalonil }\end{array}$ \\
\hline $\begin{array}{l}\text { Physiological Effects } \\
\text { in Mammals }\end{array}$ & $\begin{array}{l}\text { delayed sexual } \\
\text { maturation, induced lipid } \\
\text { peroxidation in } \\
\text { hepatocytes, renal toxin, } \\
\text { possible carcinogen }\end{array}$ \\
\hline $\begin{array}{l}\text { Physiological Effects } \\
\text { in Fish }\end{array}$ & $\begin{array}{l}\text { affected immune } \\
\text { responses, alterd } \\
\text { respiration, biased sex } \\
\text { ratios, reduced fry } \\
\text { activity }\end{array}$ \\
\hline $\begin{array}{l}\text { Physiological Effects } \\
\text { in Aquatic } \\
\text { Invertebrates }\end{array}$ & $\begin{array}{l}\text { may affect immune } \\
\text { function, highly toxic to } \\
\text { mussel glochidia and } \\
\text { juveniles }\end{array}$ \\
\hline
\end{tabular}

Physiological Effects NA

in Amphibians 


\section{Which Organisms, Life Stages, and Endpoints Are Most Sensitive?}

As with other chemicals, no particular organism or taxonomic group has been identified as more sensitive than another, as stated by Maltby and others (2009):

"... it is not clear which of the three taxonomic groups—vertebrates (fish), invertebrates, primary producers - should be the focus of attention for studies with fungicides...semi-field studies with fungicides do not suggest one common sensitive group...”.

Sensitivity may be due to (a) the organism and its life stage, (b) ecosystem effects, (c) changes in immune function, (d) oxidative stress, and (or) (e) endocrine function. Sensitivity may also be seen in the presence of (f) mixtures.

\section{Organisms and Life Stages}

Several approaches have been taken to identify the most sensitive species, life stage, and endpoints for environmental assessments. Ankley and colleagues (2009) suggest this could be achieved based on knowledge of the mechanism(s) of action of a chemical or suite of related chemicals (for example, antiandrogens), identification of molecular markers for the affected biochemical pathways, and demonstration that alterations in those markers results in significant changes in functional endpoints (for example, reproductive success or immune function). This approach combines the EPA's tiered testing framework for aquatic organisms (in vitro tests and short-term in vivo tests) with genomics and computational biology to create predictive toxicology tools and is being developed for endocrine disrupting chemicals in fish. As noted by these authors, this basic conceptual approach could be used for many chemicals and levels of biological organization. With scant information on the effects of fungicides on aquatic organisms, developing such an approach for ecosystem level assessment would be a formidable challenge.

To determine if there are consistent taxonomic differences in sensitivity to fungicides, and if these are related to toxic mode of action, Maltby and others (2009) used numerous datasets for semifield and laboratory exposures of aquatic organisms to fungicides to compare the median concentration that effects a response in 50 percent of the organisms (EC50) for fungicides with different toxic modes of action, to construct species sensitivity distributions (SSDs), and to derive threshold values. These authors found fish and invertebrates fell into two broad groups: Fish were less sensitive than invertebrates to ethylene bisdithio-carbamate (EBDC) fungicides (note: EBDC fungicides are not covered in this review) and to sterol-biosynthesis-inhibiting fungicides, but more sensitive than invertebrates to non-EBDC fungicides with multi-site activity. No other significant taxonomic differences were found. One conclusion that can be drawn is that there is no one toxic MOA that is consistently more toxic to nonfungal organisms than another. A comparison of the relative toxicities of fungicides representing all MOAs supports this view (fig. 1).

While cladocerans (Daphnia spp.) are often sensitive to chemical stress, particularly the early life stages (Marshall, 1978, cited in Warming and others, 2009), recent work suggests understudied groups, specifically freshwater mussels and gastropods, warrant further study. Freshwater mussels can be quite sensitive to pesticides, including fungicides (table 4). However, the acute sensitivity of their early life stages (glochidia, juveniles) to these chemicals, relative to Daphnia, is inconsistent (Bringolf and others, 2007b). Our current lack of understanding of hormonal and environmental regulation of reproduction in freshwater mussels hinders our ability to study the effects of fungicides on this endpoint, which may be even more sensitive than the larval and metamorph stages currently used for testing. Freshwater gastropods may be more sensitive to endocrine disruptors than standard EPA test organisms (Ducrot and others, 2010). Mattheissen suggests that mollusks, and gastropods in particular, should be incorporated as standard test organisms for endocrine disrupting compounds (EDCs) due to 
their sensitivity to these chemicals, their ecological importance, and because mollusk species outnumber all invertebrate groups, except insects (Matthiessen, 2008).

\section{Ecosystem Effects}

In the few studies of ecosystem effects of fungicides, alterations in the community structure of zooplankton and algae are the most frequently noted response; there are few studies on ecosystem function. Community changes in fungicide-treated ecosystems have been attributed to both direct toxicity and to secondary effects, including interspecific interactions. It has been proposed that declines in key grazers, such as daphnids, would decrease grazing, increase algal populations, and decrease water transparency, leading to subsequent deterioration of macrophytes (Warming and others, 2009). In this light, it becomes clear that single species EC50 values likely do not represent the worst case scenario (Gustafsson and others, 2010). There is evidence that fundamental ecosystem processes, such as leaf litter breakdown, can be deleteriously affected by fungicide exposure. For example, exposure to $65 \mu \mathrm{g} / \mathrm{L}$ tebuconazole for 5 weeks affected fungal biomass and sporulation associated with leaf material and affected assimilation efficiency and physiological fitness of freshwater leaf-shredding amphipods, pointing to the need for incorporation of fundamental ecosystem processes in aquatic environmental risk assessment protocols (Zubrod and others, 2011).

Immune Function

Although many fungicides and toxicants provoke biochemical changes consistent with immune function, such as altered reactive-oxygen production, this endpoint is seldom studied. The few studies found include chlorothalonil effects on reactive oxygen production and macrophage function in isolated fish and oyster cells (Baier-Anderson and Anderson, 1998, 2000a, 2000b), and chlorothalonil effects on innate immunity in whole fish (Shelley and others, 2009).

\section{Oxidative Stress}

In addition to its role in immune response, reactive oxygen is a potent toxin, capable of oxidizing most cellular components (for example, nucleic acids, proteins, membranes, and lipids), resulting in significant damage, disruption of enzyme activity, and reduction of cellular integrity (Li and others, 2010). The brain, with its high density of lipid-rich neural tissue, is particularly susceptible to lipid peroxidative damage compared to other organs ( $\mathrm{Li}$ and others, 2010), indicating oxidative stress could lead to behavioral changes. Thus, oxidative stress, as evaluated by reactive oxygen generation, lipid damage, and (or) behavioral change, could be an important sublethal endpoint for fungicide toxicity studies. 


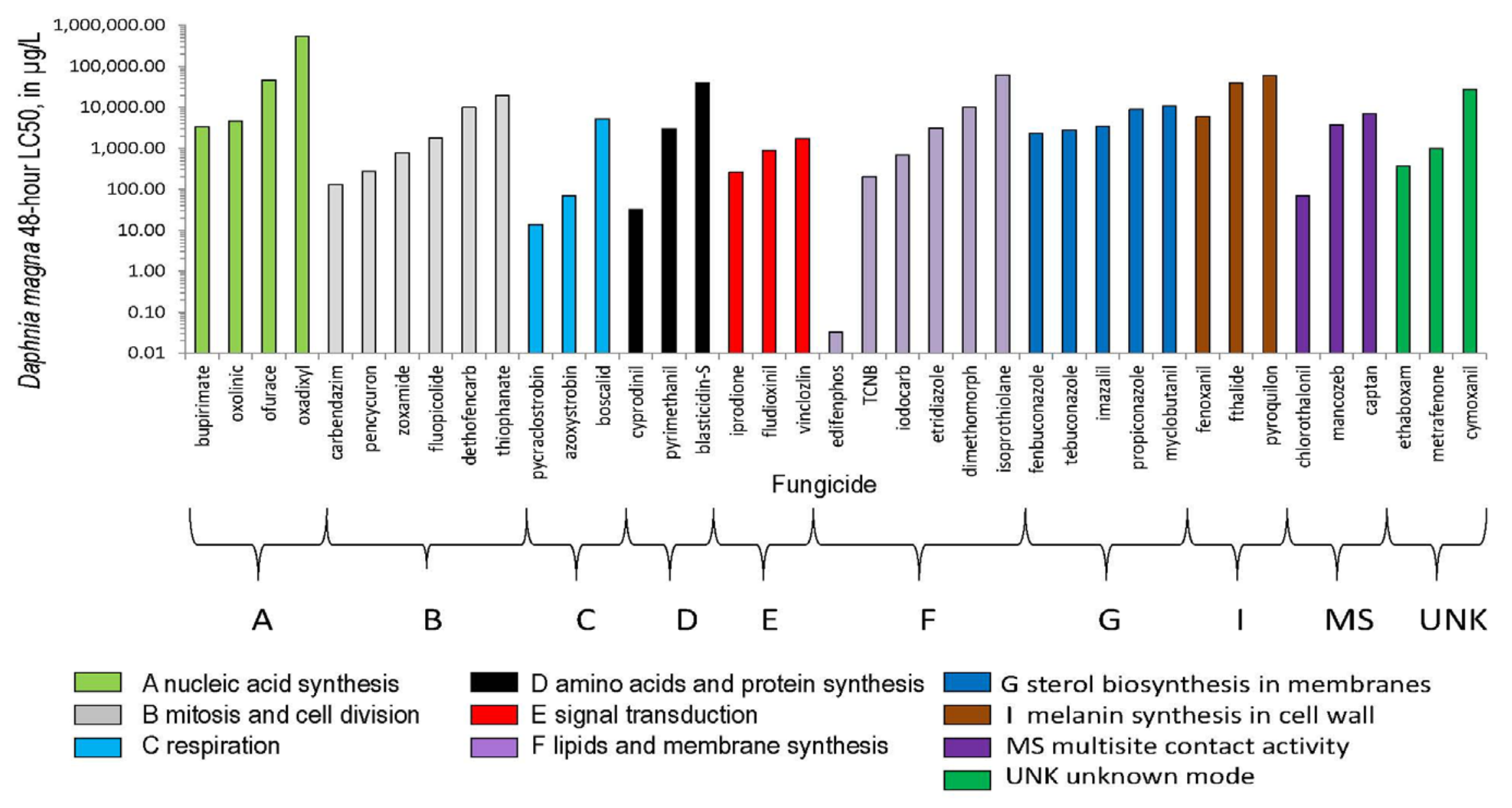

Figure 1. Graph depicting the relative toxic potency of a variety of fungicides to Daphnia magna grouped by mode of action. (48 hour LC50 is the concentration that effects a lethal response in 50 percent of the organisms in 48 hours. Daphnia magna LC50 values are from University of Hertfordshire (2012). 
Table 4. Lowest reported lethal (EC50, LC50) and NOEC/NOAEC values for aquatic organisms

[FRAC, Fungicide Resistance Action Committee; MOA, mode of action; 25 h EC50, concentration that effects a response in 50 percent of the organisms by 24 hours; $48 \mathrm{~h}$ EC50, concentration that effects a response in 50 percent of the organisms by 48 hours; 96 h LC50, concentration that effects a response in 50 percent of the organisms by 96 hours; NOAEC, no observable adverse effects concentration; h, hours; NA, no data available; > , greater than; < , less than; all values are in micrograms per liter]

\begin{tabular}{|c|c|c|c|c|c|c|c|c|}
\hline $\begin{array}{l}\text { FRAC MOA } \\
\text { Fungicide }\end{array}$ & $\begin{array}{l}\text { Invertebrate } \\
48 \text { h EC50 }\end{array}$ & $\begin{array}{l}\text { Invertebrate } \\
\text { chronic } \\
\text { NOAEC }^{a}\end{array}$ & $\begin{array}{l}\text { Fish } \\
96 \mathrm{~h} \\
\text { LC50 }\end{array}$ & $\begin{array}{c}\text { Fish } \\
\text { chronic } \\
\text { NOAECa }\end{array}$ & $\begin{array}{c}\text { Freshwater mussels } \\
\text { glochidia, juvenile } \\
\text { EC50 }\end{array}$ & $\begin{array}{c}\text { Marine bivalves } \\
96 \mathrm{~h} \text { shell } \\
\text { deposition } \\
\text { EC50 } \\
\end{array}$ & $\begin{array}{l}\text { Zooplantkon } \\
\text { Community } \\
\text { Effects }\end{array}$ & Frogs \\
\hline $\begin{array}{l}\text { Mitosis and cell division } \\
\text { Zoxamide }\end{array}$ & $>780$ & 39 & 156 & 3.48 & NA & 715 & NA & NA \\
\hline $\begin{array}{r}\text { Respiration } \\
\text { Boscalid }\end{array}$ & $5,300^{\mathrm{b}}$ & 790 & 2,700 & 116 & NA & 1,000 & NA & NA \\
\hline Azoxystrobin & 260 & 44 & 470 & 147 & NA & NA & $<2$ & $10^{\mathrm{C}}$ \\
\hline Pyraclostrobin & 15.7 & 4 & 6.2 & 2.35 & $\begin{array}{r}480(24 \mathrm{~h}) \\
80(48 \mathrm{~h}) \\
30(96 \mathrm{~h})\end{array}$ & NA & NA & NA \\
\hline $\begin{array}{l}\text { Signal transduction } \\
\text { Fludioxonil }\end{array}$ & 900 & $<19$ & 470 & 19 & NA & $370^{d}$ & NA & NA \\
\hline $\begin{array}{l}\text { Sterol biosynthesis in mer } \\
\text { Myclobutanil }\end{array}$ & 11,000 & - & 2,400 & 980 & NA & NA & NA & NA \\
\hline Fenarimol & 6,800 & $113^{\mathrm{e}}$ & 900 & 180 & NA & NA & NA & NA \\
\hline $\begin{array}{l}\text { Multi-site contact activity } \\
\text { Chlorothalonil }\end{array}$ & 54 & 39 & 10.5 & 8.5 & $\begin{array}{rr}0.97(48 h) \\
280 & (96 h)\end{array}$ & 3.6 & NA & NA \\
\hline
\end{tabular}

${ }^{\mathrm{a}}$ Chronic exposure times vary, typically 21 or $28 \mathrm{~d}$.

${ }^{\mathrm{b}}$ Considered an underestimation of toxicity due to problems with test conditions (Aubee and others, 2010b).

${ }^{c}$ Chronic exposure to this concentration from fertilization through metamorphosis had no effect (Johansson and others, 2006).

${ }^{\mathrm{d}}$ Source: Pest Management Regulatory Agency, 2006b.

${ }^{\mathrm{e}}$ No observable effects concentration. 


\section{Endocrine Effects}

Several fungicides in this review have effects consistent with endocrine disruption (tables 2 and 3). However, endocrine endpoints are seldom assessed in fungicide studies, and standard toxicity tests may not detect the sublethal effects of endocrine-active chemicals. As used in this review, an endocrine disruptor is a chemical that affects hormone action either by altering hormone synthesis and (or) degradation, or acting as a mimic or antagonist. Endocrine effects can occur at low concentrations, may exhibit complex dose-response relationships (for example, inverted $U$ dose-response curves), or be manifested in later life stages (Ducrot and others, 2010). New testing guidelines for endocrine disruptors are being developed by the Organisation for Economic Cooperation and Development (Organisation for Economic Cooperation and Development, 2011). These testing guidelines incorporate partial and full life-cycle testing for vertebrates and invertebrates, including aquatic organisms, and should be consulted when designing experiments to assess potential endocrine-active fungicides and (or) mixtures. Experimental design for testing endocrine-active substances can greatly influence the outcome (Matthiessen, 2008). Choice of in vitro and (or) in vivo approaches, cell line, species, life stage, gender, length of exposure, endpoints and time points chosen, including generational effects, are among the many factors that must be carefully considered.

\section{Mixtures}

Some fungicides only exhibit significant toxicity when combined with other chemicals. Mixtures of fungicides, but not individual fungicides, caused endocrine disruption of reproduction in mice (Jacobsen and others, 2010). In binary mixtures, azole fungicides increased the toxicity of pyrethroid insecticides to daphnids (Norgaard and Cedergreen, 2010; Bjergager and others, 2011). While most effects of binary mixtures are fairly well predicted by concentration-addition models, including pesticides with different modes of action (Norgaard and Cedergreen, 2010), strong synergism is seen with one class of fungicides, the ergosterol biosynthesis inhibiting (EBI) (also known as DMI) fungicides. Binary combinations of these pesticides increased insecticide toxicity fourfold to twelvefold in Daphnia. Pesticides tested to date for synergism include the fungicides prochloraz, epoxiconazole, propiconazole, tebuconazole, fenpropidin, fenpropimorph, and azoxystrobin, and the insecticides alphacypermethrin, chlorfenviphos, dimethodate, pirimicarb, and esfenvalerate. Some of these can occur at synergizing levels in the environment ( $175 \mu \mathrm{g}$ propiconazole/L after a storm event) (Norgaard and Cedergreen, 2010). There has been a call for more work on identifying the occurrence of azole fungicides in both water and sediment, the effects of pesticide binding to organic matter on pesticide toxicity, and additional endpoints and species for evaluating fungicide synergism (Norgaard and Cedergreen, 2010).

\section{Detailed Summaries for Select Fungicides by Fungicide Resistance Action Committee Mode of Action}

\section{Fungicide Resistance Action Committee Mode of Action B: Mitosis and Cell Division}

\section{Zoxamide}

\section{Environmental Fate in Aquatic Systems}

Zoxamide may persist in the environment for days to months (U.S. Environmental Protection Agency, 2011a), absorbed to sediments and organic matter (table 5). Because it is practically immobile, 
it is not expected to leach into groundwater. Once in water, however, it is labile to hydrolysis (DT50 15.7 days), photolysis (DT50 $8 \mathrm{~d}$ ), and microbial degradation (table 5). Bioconcentration factors for fish and invertebrates vary, but are quite low (BCF 115) (table 5) (U.S. Environmental Protection Agency, 2011a; University of Hertfordshire, 2012).

Mode of Toxic Action in Fungi

Zoxamide [3,5-dichloro-N-(3-chloro-1-ethyl-1-methyl-2-oxopropyl)-4-methylbenzamide] is a benzamide fungicide that acts as an antitubulin, arresting mitosis and cell division (Young and Slawecki, 2001; Young and others, 2006; Fungicide Resistance Action Committee, 2012) (table 1).

Biochemical Effects in Mammals

Mammals are capable of completely detoxifying the mitosis-inhibiting properties of this fungicide, likely through metabolite conjugation with glutathione or glucuronic acid (Oesch and others, 2010). Zoxamide is not genotoxic and is considered not likely to be a human carcinogen (U.S.

Environmental Protection Agency, 2001) (tables 2 and 3).

Toxic Effects in Freshwater Organisms

Zoxamide is categorized by the EPA as highly toxic to freshwater fish and highly to very highly toxic to freshwater, marine, and estuarine invertebrates (U.S. Environmental Protection Agency, 2001) (tables 4 and 6, see appendix 1 for a definition of toxicity categories). The sublethal effects of zoxamide on aquatic organisms are unknown.

Relationship Between Zoxamide Fungal MOA and Effects in Nonfungal Organisms

The Phase II enzyme pathways mammals use to detoxify zoxamide are also present in aquatic vertebrates (Andersson and others, 1985) and active to a limited extent in invertebrates (Navarro and others, 2011). However, unlike in mammals, zoxamide is highly toxic to fish and aquatic invertebrates (tables 4 and 6). Studies are needed to identify what biochemical pathways are involved in the toxicity of this fungicide to aquatic organisms. As zoxamide inhibits cell division in fungi by binding $\alpha$-tubulin and inhibiting-tubulin polymerization, tubulin binding is a likely starting point for investigations of zoxamide mechanisms of toxicity in fish and invertebrates

\section{Fungicide Resistance Action Committee Mode of Action C: Respiration}

\section{Boscalid}

Environmental Fate in Aquatic Systems

Boscalid is expected to be environmentally persistent (table 5), and while expected to occur in low concentrations in surface water and groundwater (Pest Management Regulatory Agency, 2004; Aubee and Lieu, 2010a), the USGS has found concentrations as high as $36 \mu \mathrm{g} / \mathrm{L}$ in some surface waters (Smalling and Orlando, 2011). Boscalid is quickly depurated in fish ( $\mathrm{t}_{1 / 2}<1$ day) (Pest Management Regulatory Agency, 2004). Bioaccumulation in benthic invertebrates in contact with sediments has not been measured, but may be important due to boscalid partitioning to sediment (Pest Management Regulatory Agency, 2004). 
Table 5. Physical-chemical properties and bioconcentration factors (BCF) for selected fungicides

[All data are from University of Hertfordshire (2012) except where noted. FRAC, Fungicide Resistance Action Committee; MOA, mode of action; $\mu \mathrm{g} / \mathrm{L}$, micrograms per liter; DT50, the length of time needed for 50 percent of the compound to dissipate from the soil (Soil DT50), from water due to hydrolysis (Hydrolysis DT50), from water due to phololysis (Photolysis DT50); Koc, organic carbon-to-water partition coefficient, that is, the ratio of pesticide concentration dissolved in organic carbon and dissolved in water; Kow, the octanol-to-water partition coefficient, that is, the ratio of the pesticide concentration in octanol and water; $\mathrm{ml} / \mathrm{g}_{\mathrm{oc}}$, milliliters per gram organic carbon; BCF, bioconcentration factor; med, medium; NA, no data available; NU, data not useful; also see Abbreviations]

\begin{tabular}{|c|c|c|c|c|c|c|c|c|c|c|}
\hline $\begin{array}{l}\text { FRAC MOA } \\
\text { Fungicide }\end{array}$ & $\begin{array}{l}\text { Water } \\
\text { solubility } \\
\text { ( } \mu \mathrm{g} / \mathrm{L})\end{array}$ & $\begin{array}{l}\text { Hydrolysis } \\
\text { (DT50) } \\
\text { (days) }\end{array}$ & $\begin{array}{l}\text { Photolysis } \\
\text { (DT50) } \\
\text { (days) }\end{array}$ & $\begin{array}{c}\text { Soil } \\
\text { DT50 } \\
\text { (days) }\end{array}$ & Mobility & $\begin{array}{l}\text { Log } \\
\text { Kow }\end{array}$ & $\begin{array}{c}\text { Koc } \\
\left(\mathrm{ml} / \mathrm{g}_{\mathrm{oc}}\right)\end{array}$ & $\begin{array}{l}\text { Water- } \\
\text { sediment } \\
\text { (DT50) } \\
\text { (days) }\end{array}$ & $\begin{array}{l}\text { Persistence } \\
\text { in water and } \\
\text { soil (aerobic) }\end{array}$ & $\mathrm{BCF}$ \\
\hline \multicolumn{11}{|l|}{ Mitosis and cell division } \\
\hline Zoxamide & 681 & 15.7 & 8 & 60 & Low & 3.76 & 1,124 & 5.8 & Low and med & 115 \\
\hline \multicolumn{11}{|l|}{ Respiration } \\
\hline Boscalid & 4,600 & stable & 30 & 200 & Low & 2.96 & 1,100 & NA & High and high & 107 \\
\hline Azoxystrobin & 6,700 & stable & 8.7 & 70 & Low to medium & 2.50 & 589 & 205 & Low and med & NA \\
\hline Pyraclostrobin & 1,900 & stable & 1.7 & 32 & Immobile & 3.99 & 9304 & 28 & Low and med & 706 \\
\hline \multicolumn{11}{|c|}{ Amino acid and protein synthesis } \\
\hline Pyrimethanil & 121,000 & stable & stable & 55 & Medium & 2.84 & 835 & 80 & Med and med & NA \\
\hline \multicolumn{11}{|l|}{ Signal transduction } \\
\hline Fludioxonil & 1,800 & stable & 10 & 164 & Immobile & 4.12 & $145-600$ & 575 & Med and high & 366 \\
\hline \multicolumn{11}{|c|}{ Sterol biosynthesis in membranes } \\
\hline Myclobutanil & 132,000 & stable & 15 & 560 & Low & 2.89 & $\mathrm{NU}^{\mathrm{b}}$ & 626 & High and high & NA \\
\hline Fenarimol & 13,700 & stable & 0.5 & 250 & Low to medium & 3.69 & $406-684$ & stable & High and high & 113 \\
\hline \multicolumn{11}{|c|}{ Multi-site contact activity } \\
\hline Chlorothalonil & 810 & stable & 65 & 22 & Low & 2.94 & 850 & 0.1 & Med and med & 100 \\
\hline
\end{tabular}

${ }^{a}$ relative persistence is based on hydrolysis DT50 (water) and Koc (soil) as defined \{U.S. Environmental Protection Agency, 2012b \#758

${ }^{b}$ NU-not useful; Koc is not a good measure of mobility for myclobutanil as sorption does not appear to be correlated with soil organic carbon, see Table 2.1 in (U.S. Environmental Protection Agency, 2009b) 
Mode of Toxic Action in Fungi

Boscalid [2-chloro-N-(4-chlorobiphenyl-2-yl) nicotinamide) is an anilide (carboxamide] fungicide, disrupting fungal respiration and subsequent ATP production by inhibition of the enzyme succinate dehydrogenase via complex II of the mitochondrial electron transport chain (Fungicide Resistance Action Committee, 2012) (table 1).

Biochemical Effects in Mammals

A range of acute, chronic, developmental, and generational toxicity tests indicates boscalid toxicity to mammals is low. In dietary studies with mice exposed for 90 days to 2 years to doses of 2,500 x $10^{3}$ to $5,000 \times 10^{3} \mu \mathrm{g} / \mathrm{kg}$ body weight provoked biochemical responses, including increased liver enzymes (alanine aminotransferase), increased serum gamma-glutamyl transferase, and induction of thyroid follicular cell adenomas; however, the enzyme responses were considered an adaptive response to increased metabolic demand, and the thyroid changes were reversible when treatment ceased (Pest Management Regulatory Agency, 2004). Boscalid metabolism in mammals is via Phase I and II reactions and results in either conjugation with glucuronic acid or sulfate, or the binding of boscalid directly to glucuronide with cleavage to sulfate metabolites (Toxicology Data Network, 2007).

Toxic Effects in Freshwater Organisms

Boscalid is considered moderately to highly toxic to freshwater invertebrates, moderately toxic to fish and algae, but highly toxic to marine bivalves (Pest Management Regulatory Agency, 2004; Aubee and Lieu, 2010a, 2010b). Boscalid exceeds the EPA's level of concern for direct, acute risk of mortality to listed freshwater fish and aquatic-phase amphibians. Aubee and Lieu stated, “...boscalid may result in adverse effects on survival, growth, and (or) fecundity of aquatic animals. There is also uncertainty regarding the potential risk to benthic invertebrates, given boscalid's persistence in water and sediment.” (Aubee and Lieu, 2010b, p.13).

Data Gaps

There are no sublethal studies of boscalid effects on aquatic organisms, and acute and chronic tests are missing for some organisms, particularly invertebrates. Recent documents from the EPA (Aubee and Lieu, 2010b) indicate that studies of boscalid are needed to evaluate its (1) acute toxicity to pelagic freshwater invertebrates (the current boscalid-toxicity value is considered unreliable due to problems with precipitates in the test), (2) acute and chronic toxicity to freshwater benthic invertebrates using boscalid-spiked sediment, (3) toxicity to freshwater mussels given its high toxicity to oysters, and (4) bioaccumulation potential in benthic invertebrates.

Relationship Between Boscalid Fungal MOA and Effects in Nonfungal Organisms

Boscalid is basically nontoxic to mammals, but moderately to highly toxic to aquatic organisms (table 6). Boscalid may be affecting pathways in aquatic organisms that are different from those reported in mammals, or the difference may be explained by toxicokinetics. In mammals, intake via the gut allows first-pass metabolism by the liver; intake via the gills in fish does not facilitate this. Biochemical effects of boscalid in mammals (for example, alteration of liver enzymes) also do not appear to be related to its toxic modes of action in fungi (inhibition of succinate dehydrogenase), and provide no insights into potential target sites in aquatic organisms. Thus, with no useful data available on possible biochemical targets in aquatic organisms, boscalid's disruption of energy production in fungi via inhibition of the enzyme succinate dehydrogenase provides perhaps the best starting point for investigating potential toxic modes of action in fish and invertebrates. 
Table 6. Aquatic life benchmarks and toxicity category for select fungicides

[FRAC, Fungicide Resistance Action Committee; MOA, mode of action; LC50, concentration that is lethal to 50 percent of the organisms; invert, invertebrates; NA, no data available]

\begin{tabular}{|c|c|c|}
\hline $\begin{array}{l}\text { FRAC MOA } \\
\text { Fungicide }\end{array}$ & $\begin{array}{l}\text { Aquatic Life Benchmarks } \\
\text { for fish and invertebrates, under } \\
\text { acute and chronic exposure, in } \\
\text { micrograms per liter }\end{array}$ & Toxicity Categoryb \\
\hline $\begin{array}{l}\text { Mitosis and cell division } \\
\text { Zoxamide }\end{array}$ & $\begin{array}{l}78 \text { and } 390 \text { (acute) }^{\mathrm{c}} \\
3 \text { and } 39 \text { (chronic) }^{\mathrm{c}}\end{array}$ & $\begin{array}{l}\text { Highly toxic (fish) } \\
\text { Highly to very highly toxic (invert) }\end{array}$ \\
\hline $\begin{array}{r}\text { Respiration } \\
\text { Boscalid }\end{array}$ & $\begin{array}{l}1,350 \text { and NA (acute) } \\
116 \text { and } 790 \text { (chronic) }^{\mathrm{c}}\end{array}$ & $\begin{array}{l}\text { Moderately to highly toxic (fish) } \\
\text { Moderately to highly toxic }\end{array}$ \\
\hline Azoxystrobin & $\begin{array}{l}235 \text { and } 130 \text { (acute) } \\
147 \text { and } 44 \text { (chronic) }\end{array}$ & $\begin{array}{l}\text { Highly toxic (invert) } \\
\text { Highly toxic (fish) }\end{array}$ \\
\hline Pyraclostrobin & $\begin{array}{l}3 \text { and } 8 \text { (acute) }{ }^{c} \\
2 \text { and } 4 \text { (chronic) }^{c}\end{array}$ & $\begin{array}{l}\text { Highly to very highly toxic (fish) } \\
\text { Highly to very highly toxic (invert) }\end{array}$ \\
\hline $\begin{array}{l}\text { Amino acid and protein synthesis } \\
\text { Pyrimethanil }\end{array}$ & $\begin{array}{l}5,000 \text { and } 1,520 \text { (acute) }^{c} \\
1,600 \text { and } 970 \text { (chronic) }^{c}\end{array}$ & $\begin{array}{l}\text { Slightly toxic (fish) } \\
\text { Moderately toxic (invert) }\end{array}$ \\
\hline $\begin{array}{l}\text { Signal transduction } \\
\text { Fludioxonil }\end{array}$ & $\begin{array}{l}115 \text { and } 480 \text { (acute) }^{c} \\
19 \text { and } 16 \text { (chronic) }^{c}\end{array}$ & $\begin{array}{l}\text { Highly toxic (fish) } \\
\text { Highly toxic (invert) }\end{array}$ \\
\hline $\begin{array}{l}\text { Sterol biosynthesis in membranes } \\
\text { Myclobutanil }\end{array}$ & $\begin{array}{l}1,200 \text { and 5,500 (acute) } \\
980 \text { and NA (chronic) }\end{array}$ & $\begin{array}{l}\text { Moderately toxic (fish) } \\
\text { Slightly toxic (invert) }\end{array}$ \\
\hline Fenarimol & $\begin{array}{l}\text { 2,050 and 3,400 (acute) } \\
85 \text { and } 113 \text { (chronic) }\end{array}$ & $\begin{array}{l}\text { Moderately toxic (fish) } \\
\text { Highly toxic (invert) }\end{array}$ \\
\hline $\begin{array}{l}\text { Multi-site contact activity } \\
\text { Chlorothalonil }\end{array}$ & $\begin{array}{l}5.25 \text { and } 1.8 \text { (acute) } \\
3 \text { and } 0.6 \text { (chronic) }\end{array}$ & $\begin{array}{l}\text { Very highly toxic (fish) } \\
\text { Very highly toxic (invert) }\end{array}$ \\
\hline
\end{tabular}

${ }^{\mathrm{a}}$ These values are derived from distributions and are threshold criteria below which risks are minimal (U.S. Environmental Protection Agency, 2012).

${ }^{\mathrm{b}}$ U.S. Environmental Protection Agency categories, see Appendix 1.

cestimated from acute and chronic LC50 values as described (U.S. Environmental Protection Agency, 2012). 


\section{Azoxystrobin}

\section{Environmental Fate in Aquatic Systems}

Azoxystrobin is considered to have low-to-medium persistence in the environment (table 5) (U.S. Environmental Protection Agency, 1997; Bartlett and others, 2002; Pest Management Regulatory Agency, 2007). Absorption to sediment, microbial degradation, and indirect photolysis are significant pathways of loss, with photodegradation being the most prominent (table 5).

\section{Mode of Toxic Action in Fungi}

Azoxystrobin (methyl ( $\alpha \mathrm{E})$-2-[[6-(2-cyanophenoxy)-4-pyrimidinyl]oxy]- $\alpha$ (methoxymethylene)benzeneacetate) is a broad-spectrum systemic fungicide belonging to the group bmethoxyacrylate strobilurins (Fungicide Resistance Action Committee, 2012). In 2002, it was the most widely used fungicide in the world (Bartlett and others, 2002) and in 2011, it was the leading product driving the fungicide market (Troy, 2011). Strobilurins exert their toxic effects on fungi by inhibiting mitochondrial respiration. Specifically, they bind to the quinol oxidation (Qo) site of mitochondrial cytochrome b, which blocks electron transfer from cytochrome b to cytochrome c1, stopping the production of adenosine triphosphate (ATP), and thereby disrupting the energy cycle and preventing fungal growth (Bartlett and others, 2002). An additional consequence of this action is the release of electrons from the respiratory chain, producing cellular oxidative stress (Kim and others, 2007).

\section{Biochemical Effects in Mammals}

Azoxystrobin is considered relatively nontoxic to mammals, being rapidly metabolized and cleared, mainly via conjugation with glucuronide (Pest Management Regulatory Agency, 2007). The main target sites are the bile duct and the liver, resulting in pathogenic changes in these tissues at doses of 34,000 $\mu \mathrm{g} / \mathrm{kg}$ body weight and above (Pest Management Regulatory Agency, 2007) (tables 2 and 3). In the human hepatoma derived cell line HepG2, exposure to $4 \times 10^{-7}$ to $2.4 \times 10^{-4} \mathrm{M}(1,600$ to 100,850 $\mu \mathrm{g} / \mathrm{L}$ ) azoxystrobin produced a dose-related cytochrome P4501A1 (CYP1A1) induction pattern that coincided with cytotoxicity (Rudzok and others, 2009). Azoxystrobin is not considered neurotoxic, mutagenic, genotoxic, teratogenic, or to be a reproductive toxin. It is classified as an inhalation hazard for humans by the European Union (Bartlett and others, 2002).

\section{Toxic Effects in Freshwater Organisms}

In contrast to mammals, azoxystrobin is highly toxic to fish, invertebrates, and freshwater algae (Pest Management Regulatory Agency, 2007; Ochoa-Acuna and others, 2009) (tables 4 and 6); two of its degradates may be slightly toxic to daphnids (U.S. Environmental Protection Agency, 1997). It appears to have little adverse effect on amphibians at environmentally relevant concentrations (1 to 10 $\mu \mathrm{g} / \mathrm{L}$ from fertilization to metamorphosis (Johansson and others, 2006).

The effects of azoxystrobin on physiological processes in Daphnia magna differ among clones, including acute sensitivity (from 71 to $277 \mu \mathrm{g} / \mathrm{L}$ 48-hour EC50s), respiration, age at first reproduction, and (increased or decreased) fecundity (Warming and others, 2009). Other physiological endpoints affected include swimming velocity, mandible movements, and heart rate, among others (cited in Warming and others, 2009; (Friberg-Jensen and others, 2010). Unlike other pesticides shown to increase invertebrate drift in lotic systems (Muirhead-Thomson, 1978; Cuffney and others, 1984; Wallace and others, 1989; Kreutzweiser and Sibley, 1991; Davies and Cook, 1993; Hose and others, 2002; Beketov and Liess, 2008), including the dicarboximide fungicide iprodione (Beketov and Liess, 2008), 
azoxystrobin (at $16.5 \mu \mathrm{g} / \mathrm{L}$ NOEC) did not initiate downstream drift in the amphipod Gammarus pulex (Beketov and Liess, 2008).

The mechanism by which azoxystrobin exerts its toxic effects in fish is not known; however, recent work suggests it may, as in fungi, impair mitochondrial respiration. Olsvik and others (2010) report significant alterations in liver, muscle, and blood parameters associated with mitochondrial respiration, oxidative stress, and cell growth and proliferation in Atlantic salmon (Salmo salar) smolts exposed to the fungicide formulation Amistar [active ingredient (a.i.) is azoxystrobin] for 4 days, a duration representative of their exposure during downstream migration through agricultural runoff. The doses used in this study (122 and $352 \mu \mathrm{g}$ a.i./L) are well above the maximum of $4.6 \mu \mathrm{g} / \mathrm{L}$ measured in U.S. surface waters (Smalling and Orlando, 2011). Significant changes in biomarkers of oxidative stress (catalase), mitochondrial respiration (MAPK1, IGFBP1,TNFR), stress/biotransformation (CYP1A), and general stress (transferrin), as well as plasma glucose and other biochemical parameters, were also noted in these fish. The authors speculate that long-term exposure could affect fish growth. Studies in zebrafish found genotoxic effects (DNA damage) in liver and spermatocytes of adult males exposed to an environmentally realistic concentration of azoxystrobin $(0.5 \mu \mathrm{g} / \mathrm{L})$ for 3 weeks (Bony and others, 2010). Such effects could have population-level impacts by altering xenobiotic metabolism (liver) and reproductive success (sperm) (Bony and others, 2010).

In binary mixtures, the toxicity of azoxystrobin to Daphnia magna was significantly increased in the presence of the imidazole fungicide prochloraz (Cedergreen and others, 2006). The authors suggest inhibition of CYP450-related pesticide metabolism as the most likely mechanism.

At low, environmentally relevant concentrations, azoxystrobin may significantly alter ecosystem dynamics by deleteriously affecting key species such as daphnids. The most notable effects have been seen in freshwater microcosm studies in which $2 \mu \mathrm{g} / \mathrm{L}$ or less azoxystrobin significantly altered zooplankton community structure (Gustafsson and others, 2010). Significant effects were also found on the composition of microcosm phytoplankton communities, likely due to indirect effects of altered zooplankton grazing pressure.

Azoxystrobin appears to have little adverse effect on amphibians at environmentally relevant doses. In acute tests, exposure of frog (Rana temporaria) tadpoles to azoxystrobin (from 30 to $500 \mu \mathrm{g} / \mathrm{L}$ ) for 72 hours had no significant effect on survival (Johansson and others, 2006). In the same study, chronic exposure to 1 to $10 \mu \mathrm{g} / \mathrm{L}$ azoxystrobin from fertilization through metamorphosis had no effect on growth, weight, age at metamorphosis, or survival. Similarly, Belden and others (2010) found direct spray application of the 2-fungicide formulation Quilt to toads produced little to no acute toxicity. At the Quilt application rate to test chambers $\left(0.13-13 \mu \mathrm{g} / \mathrm{cm}^{3}\right.$ propiconazole $+0.076-76 \mu \mathrm{g} / \mathrm{cm}^{3}$ azoxystrobin, nominal concentrations) yielding nominal concentrations in the water of 7.4-740 $\mu \mathrm{g} / \mathrm{L}$ and $4.4-440$ $\mu \mathrm{g} / \mathrm{L}$, respectively, survival of laboratory-reared tadpoles (7 days old) and wild-caught juveniles ( 60 days post-metamorphosis) of the toad Bufo cognatus was reduced by 7-10 percent (tadpoles) and 4-22 percent (juveniles) over 72 hours (Belden and others, 2010).

\section{Data Gaps}

Additional information is needed on aquatic metabolism to improve estimates of azoxystrobin residues in surface water.

Relationship Between Azoxystrobin Fungal MOA and Effects in Nonfungal Organisms

Azoxystrobin affects mitochondrial respiration in fungi, and respiratory-associated changes in fish and invertebrates. In both fish and fungi, oxidative stress is also induced. Thus, the effects of azoxystrobin in aquatic organisms are consistent with its mechanisms of action in fungi, indicating target sites may be similar. 


\section{Pyraclostrobin}

Environmental Fate in Aquatic Systems

A major route of dissipation for pyraclostrobin is runoff (U.S. Environmental Protection Agency, 2011b). Pyraclostrobin is slightly soluble in water, is immobile in soil (though in formulations may be slightly to moderately mobile), is minimally photodegraded on soil, but rapidly photodegraded in water (Pest Management Regulatory Agency, 2003; European Commission, 2004a) (table 5), with all major transformation products extremely short-lived. Indirect photolysis may play an important role in degradation, with organic and inorganic constituents of water acting as photosensitizers. Pyraclostrobin is resistant to hydrolysis (Pest Management Regulatory Agency, 2003). Dissipation rates (DT50) of pyraclostrobin in water/sediment systems of 33 days in pond sediments and 9 days in river sediments have been reported (European Commission, 2004a). It is considered moderately persistent in sediment.

\section{Mode of Toxic Action in Fungi}

Pyraclostrobin (methyl N-[2-[[[1-(4-chlorophenyl)-1H-pyrazol-3-yl]oxy]methyl]phenyl]-Nmethoxycarbamate) is a synthetic analog of strobilurin A, a natural antifungal metabolite produced by the wood-rotting fungus Strobillurus tenacellus. Like azoxystrobin, it exerts its toxic effect on fungal respiration through inhibition of complex III, cytochrome bc1 (ubiquinol oxidase) at the Qo site (cyt b gene) in mitochondria (Bartlett and others, 2002; Fungicide Resistance Action Committee, 2012). In addition, the free radicals produced during this process disrupt mitochondrial and cytoplasmic membranes, further inhibiting fungal growth (Pest Management Regulatory Agency, 2003).

\section{Biochemical Effects in Mammals}

No information could be found regarding specific biochemical pathways by which pyraclostrobin exerts its toxic effects on mammals, necessitating only a description of general effects. Pyraclostrobin appears to have only transient effects in mammals. It is rapidly metabolized by rats via Phase I and II enzymes, resulting in hydroxylated, demethylated, and glucuronidated metabolites. In short-term (from 28 to 90 days) dietary studies, the duodenum was the target organ for all species tested, resulting in thickening of the mucosa in mice [30,000 to 40,000 $\mu \mathrm{g} / \mathrm{kg}$ body weight/day (bw/d)], hyperplasia in dogs (from 9,000 to 9,600 $\mu \mathrm{g} / \mathrm{kg}$ bw/d), and ulcers in mice (from 12,900 to 30,400 $\mu \mathrm{g} / \mathrm{kg}$ bw/d); however some of these effects were not seen with longer exposures, and some fell within historical control ranges, making the toxicological significance uncertain. Thymic atrophy and apoptosis of the lymph nodes (from 30,000 to 40,000 $\mu \mathrm{g} / \mathrm{kg}$ bw/d) in mice, and increased spleen and liver weight (from 68,800 to $79,700 \mu \mathrm{g} / \mathrm{kg}$ bw/d) in rats were observed with acute, but not chronic ( $>1$ year), exposure. In the absence of life-time studies, it was concluded that pyraclostrobin is not likely oncogenic. There was no evidence that it is a reproductive toxin, a teratogen, a neurotoxin, or genotoxic (Pest Management Regulatory Agency, 2003). It does have developmental effects during embryogenesis at maternally toxic doses (European Commission, 2004a).

\section{Toxic Effects in Freshwater Organisms}

Unlike in mammals, pyraclostrobin is highly to very highly toxic to invertebrates, vertebrates, and algae in freshwater, estuarine, and marine systems (Pest Management Regulatory Agency, 2003; Ochoa-Acuna and others, 2009; U.S. Environmental Protection Agency, 2011b) (tables 4 and 6). Pyraclostrobin is more toxic than azoxystrobin, possibly due to its greater lipophilicity (Bartlett and others, 2002) (table 5). Studies in bluegill sunfish (Lepomis macrochirus) indicate pyraclostrobin is absorbed but rapidly lost, with greater than 90 percent of accumulated residues lost from fish tissues 
within 2 to 3 days of depuration (Pest Management Regulatory Agency, 2003; U.S. Environmental Protection Agency, 2011b).

Very few studies have reported pesticide effects on freshwater mussels. However, in those that have, pyraclostrobin was found to be highly to very highly toxic to the freshwater mussel, Lampsilis siliquoidea, adversely affecting viability of glochidia and reducing juvenile survival (Bringolf and others, 2007b). The three fungicides tested (pyraclostrobin, chlorothalonil, and propiconazole) were more toxic than any of the other pesticides tested, including fipronil and permethrin (insecticides) and atrazine and pendimethalin (herbicides), which were found to not be acutely toxic. Of the three fungicides tested, pyraclostrobin (EC50 range 30 to $480 \mu \mathrm{g} / \mathrm{L}$ ) and chlorothalonil (EC50 range 40 to 280 $\mu \mathrm{g} / \mathrm{L}$ ) were over 200 times more toxic than propiconazole (EC50 range 10,000 to 20,750 $\mu \mathrm{g} / \mathrm{L}$ ). The toxicity of sediment-bound fungicides to these sediment-dwelling organisms is unknown but could be significant.

\section{Data Gaps}

Whole-sediment acute-toxicity studies for freshwater and marine invertebrates are needed (U.S. Environmental Protection Agency, 2011b).

Relationship Between Fungicide MOA and Effects in Nonfungal Organisms

Pyraclostrobin is rapidly cleared in mammals via Phase I and II metabolism, which likely explains its low toxicity to this group. Although aquatic organisms have Phase I and II metabolic capacity, rates of xenobiotic metabolism in these animals are generally much lower than in mammals (Stegeman and Hahn, 1994), which may explain the high toxic potency of pyraclostrobin to aquatic organisms. However, depuration studies in fish indicate pyraclostrobin is rapidly cleared, with greater than 90 percent depurated within the first 2 to 3 days (Pest Management Regulatory Agency, 2003), making it unclear why it is so toxic to these aquatic vertebrates. Inhibition of respiration via complex III and the disruption of membranes by free radicals in fungi deserve attention as possible target sites of pyraclostrobin in aquatic organisms.

\section{Fungicide Resistance Action Committee Mode of Action D. Amino Acids and Protein Synthesis}

\section{Pyrimethanil}

\section{Environmental Fate in Aquatic Systems}

The following information is taken from three reports (New York State Department of Environmental Conservation, 2005; Pest Management Regulatory Agency, 2006a; Australian Pesticides and Veterinary Medicines Authority, 2010). Pyrimethanil is stable to hydrolysis and photolysis (table 5), partitions rapidly from water to sediment, and is expected to persist in anaerobic water/sediment systems (half-life>365 days) (New York State Department of Environmental Conservation). Aerobic metabolism is expected to be the major route of dissipation. Water-sediment DT50 is 80 days (University of Hertfordshire, 2012), but accumulation is possible in aquatic systems that are treated repeatedly (U.S. Environmental Protection Agency, 2010). Pyrimethanil is not expected to leach into groundwater.

\section{Mode of Toxic Action in Fungi}

Pyrimethanil (4,6-dimethyl-N-phenyl-2-pyrimidinamine) belongs to the anilinopyrimidine fungicides (table 1). It disrupts synthesis of the amino acid methionine in fungi, thereby inhibiting fungal secretion of enzymes that degrade the cell walls of the host plant that are necessary for fungal 
infection (Milling and Richardson, 1995; Fritz and others, 1997; Fungicide Resistance Action Committee, 2012).

Biochemical Effects in Mammals

Pyrimethanil produces thyroid tumors and exhibits antithyroid activity in rats (Hurley and others, 1998). Although not all potential sites of action have been studied, pyrimethanil has been reported to increase metabolism and excretion of thyroid hormone in the liver via increased hepatic UDPGT activity (that metabolizes T4) and serum clearance of T4, increase serum thyroid-stimulating hormone levels, and produce cellular hypertrophy, hyperplasia, and (or) increased thyroid weight (specific dose of pyrimethanil was not provided, but rather the range of highest dose tested of 21 pesticides, of which pyrimethanil was one: from 13,000 to 1,000,000 $\mu \mathrm{g} / \mathrm{kg} /$ day, Hurley and others, 1998). All antithyroidal effects were reversible following cessation of treatment, consistent with a thyroid-pituitary MOA. The EPA classifies pyrimethanil as a possible human carcinogen, the carcinogenic MOA being disruption in the thyroid-pituitary status (New York State Department of Environmental Conservation, 2005).

Toxic Effects in Freshwater Organisms

Pyrimethanil is moderately toxic to invertebrates and slightly toxic to fish (New York State Department of Environmental Conservation, 2005; Pest Management Regulatory Agency, 2006a) (tables 4 and 6).

Data Gaps

Sublethal studies of pyrimethanil on aquatic organisms have not been conducted. As this fungicide rapidly partitions into sediments, effects on potentially sensitive benthic dwellers, such as freshwater mussels, should be evaluated.

Relationship Between Fungicide MOA and Effects in Nonfungal Organisms

Given the antithyroid action of pyrimethanil in mammals, its effects on the thyroid-pituitary axis, thyroid hormone levels, and resulting changes in development and growth should be evaluated in aquatic organisms. This is particularly important for amphibians where thyroid hormones play a critical role in metamorphosis (Tan and Zoeller, 2007; Laudet, 2011). Given the inhibition of methionine biosynthesis in fungi, pyrimethanil effects on synthesis of this amino acid is another potential site of action in aquatic organisms.

\section{Fungicide Resistance Action Committee Mode of Action E: Signal Transduction}

\section{Fludioxonil}

\section{Environmental Fate in Aquatic Systems}

Fludioxonil is stabile to hydrolysis but is rapidly photodegraded in water (table 5), with the small amount of parent compound that remains ( $<5$ percent) partitioning to sediment where it tends to persist ( $\mathrm{t}_{1 / 2}$ 51-154 days) (European Food Safety Authority, 2007). Due to its strong adsorptive properties, it is considered immobile in soils; however, its metabolites are highly mobile (European Food Safety Authority, 2007). Fludioxonil is not very soluble in water $(1,800 \mu \mathrm{g} / \mathrm{L}$, table 5), and thus is not likely to leach into groundwater. It should be noted, however, that because of use patterns (for example, which sites, which crops, and rates of application, among other patterns; U.S. Environmental Protection Agency, 2012b), the potential for significant runoff is considered high. Although rapidly absorbed (fludioxonil levels in whole fish reached 95 percent of the steady state concentration after 13.2 days of 
exposure to $10 \mu \mathrm{g} / \mathrm{L}$ ), fludioxonil is also rapidly depurated once exposure is terminated (DT 90 of 1.8 days) and does not significantly bioaccumulate in fish (Pest Management Regulatory Agency, 2006b).

\section{Mode of Toxic Action in Fungi}

Fludioxonil [4-(2,2-difluoro-1,3-benzodioxol-4-yl)-1H-pyrrole-3-carbonitrile] is a phenylpyrrole fungicide that interferes with the osmoregulation of fungal cells, altering the ability of fungi to sense and adapt to osmotic conditions in their environment. Under normal conditions, fungi respond to high osmolarity by synthesizing and accumulating glycerol as a compatible solute. Fludioxonil acts as an osmotic mimic, inappropriately stimulating glycerol synthesis via the mitogen-activated protein kinase pathway, leading to excessive intracellular glycerol accumulation that results in hyphal swelling, germ tube abnormalities, and cell lysis (Kanetis and others, 2008). Specifically, fludioxonil disrupts the histidine kinases in the Os-1 family involved in osmotic stress signal transduction (Motoyama and others, 2005; Vetcher and others, 2007; Fungicide Resistance Action Committee, 2012) and inhibits the protein kinase in glycerol biosynthesis (table 1).

\section{Biochemical Effects in Mammals}

Fludioxonil is not acutely toxic to mammals by oral, dermal, or inhalation routes of exposure, does not irritate skin or eyes, and exhibits no genotoxic, teratogenic, or carcinogenic potential (European Food Safety Authority, 2007).

\section{Toxic Effects in Freshwater Organisms}

Fludioxonil is highly toxic to aquatic invertebrates and fish under both acute and chronic exposures (U.S. Environmental Protection Agency, 2011c) (tables 4 and 6), highly toxic to freshwater algae and marine invertebrates (oysters, mysids), and moderately toxic to estuarine fish (sheepshead minnows) (Pest Management Regulatory Agency, 2006b). In contrast to the highly toxic parent compound, the major fludioxonil transformation products are not acutely toxic to fish or to aquatic invertebrates (European Food Safety Authority, 2007).

Data Gaps

As of December 2011, the EPA indicated that the main data gaps for fludioxonil are its ecological effects on aquatic organisms and plants. These include the need for assessment of acute toxicity of fludioxonil to Daphnia magna and rainbow trout, effects on invertebrate reproduction and fish life cycle, and chronic sediment toxicity to invertebrates, Hyalella azteca and Chironomus dilutes (U.S. Environmental Protection Agency, 2011d).

\section{Relationship Between Fungicide MOA and Effects in Nonfungal Organisms}

Nothing is known regarding the sublethal effects of fludioxonil on aquatic organisms, despite its high-toxic potency to this group. Although there is no homology known between the osmoregulatory pathways of fungi and those of vertebrate and (or) invertebrate groups, the potential for fludioxonil to interfere with osmotic regulation in aquatic organisms should be investigated. With no biochemical or molecular information on MOAs in nonfungal organisms, it is prudent to begin investigations of potential target sites in aquatic organisms by examining fludioxonil effects on mitogen-activated protein kinase pathways and histidine kinases, coupled with physiological measurements of osmoregulatory function. 


\title{
Fungicide Resistance Action Committee Mode of Action G: Sterol Biosynthesis in Membranes
}

\author{
Myclobutanil
}

Environmental Fate in Aquatic Systems

Myclobutanil is environmentally stable to hydrolysis and photolysis, is persistent (water DT50 626 days) (University of Hertfordshire, 2012), and has some mobility, the primary routes of dissipation being leaching, runoff, and spray drift (U.S. Environmental Protection Agency, 2009a)(table 5). There is some potential for atmospheric transport. Although valid measurements of Koc (organic carbon-water partition coefficient, that is, the partitioning of a compound between organic carbon and water) are not available, the EPA concludes that the Koc is probably low enough that it would not accumulate in sediment (U.S. Environmental Protection Agency, 2009a). Due to the low values for Kow (octanolwater partition coefficient, that is, the partitioning of a compound between octanol and water) for both parent and degradation products (mainly the 1,2,4-triazole degradate), it is not expected to bioaccumulate (U.S. Environmental Protection Agency, 2009a).

Mode of Toxic Action in Fungi

Myclobutanil [ $\alpha$-butyl- $\alpha$-(4-chlorophenyl)1H-1,2,4-triazole-1-propanenitrile] is a DMI triazole (table 1) that disrupts fungal membranes by inhibiting sterol biosynthesis (University of Hertfordshire, 2012). Specifically, it acts on the erg11 gene responsible for encoding sterol C14-demethylase (cytochrome P450 isozyme CYP51), inhibiting demethylation in membrane sterol biosynthesis and, thereby, preventing synthesis of ergosterol, a major membrane component in fungi (Hata and others, 2010; Fungicide Resistance Action Committee, 2012). Other DMI fungicide classes include piperazines, pyrimidines, pyridines, imidazoles, and triazoles (Hassold and Backhaus, 2009).

\section{Biochemical Effects in Mammals}

As a group, conazoles have a diversity of toxicological effects in mammals, including cancer (propiconazole and triadimefon), altered reproduction (myclobutanil and triadimefon), and altered hepatic enzymes (propiconazole, triadimefon, and myclobutanil) (Goetz and Dix, 2009; Chen and others, 2009). These effects are likely associated with their ability to induce detoxifying cytochrome P450s while inhibiting P450s involved in steroid and steroid hormone biosynthesis (Chen and others, 2009), including CYP51, an enzyme required for sterol biosynthesis in eukaryotes (Goetz and Dix, 2009). Some of the biochemical and physiological effects reported in mammals for myclobutanil are summarized in tables 2 and 3.

In in vitro assays using human breast cancer MCF-7 cells, myclobutanil competitively bound estrogen receptor, suggesting myclobutanil may have antiestrogenic activity (Okubo and others, 2004). From genomic studies in male rats, it was inferred that myclobutanil and other triazole fungicides (propiconazole and triadimefon) perturb steroid, fatty acid, and xenobiotic metabolism pathways by altering the expression of genes involved in phase I, II, and III metabolism (Aldh1a1, Cyp1a1, Cyp2b2, Cyp3a1, Cyp3a2, Slco1a4, and Udpgtr2), fatty acid metabolism (Cyp4a10, Pcx, Ppap2b), and steroid metabolism (Ugt1a1, Ugt2a1) (Goetz and Dix, 2009). In male mice receiving four daily intraperitoneal injections (270,000 $\mu \mathrm{g} / \mathrm{kg} / \mathrm{d})$, myclobutanil reduced liver levels of retinoic acid (Chen and others, 2009), a chemical that inhibits the proliferation of epithelial cells, including breast cancer cells (Chen and others, 2009). Rats dosed daily by gavage with myclobutanil (75,000 and 150,000 $\mu \mathrm{g} / \mathrm{kg} / \mathrm{d}$ ) for 14 days exhibited significantly increased levels of hepatic mRNA for Cyp2b1, Cyp3a23/3a1, and Cyp3a2, and induced activities of the cytochrome P450 enzymes pentoxyresorufin o-depentylase and benzyloxyresorufin o-debenzylase (Sun and others, 2007). 
Toxic Effects in Freshwater Organisms

Myclobutanil is only slightly toxic to invertebrates and moderately toxic to fish (U.S. Environmental Protection Agency, 2009b) (tables 4 and 6). Like other conazoles, it is rapidly metabolized by fish ( $\mathrm{t} 1 / 22.1$ days) and is not expected to biomagnify (Konwick and others, 2006).

A recent EPA report and its appendix (U.S. Environmental Protection Agency, 2009a, b) state that myclobutanil is likely to adversely affect the California red-legged frog, directly and (or) indirectly, by affecting its critical habitat. No direct toxicity data are available for the aquatic life stages of this species, and risk decisions are based on toxicity studies on eggs and larvae of fish, and indirect effects on prey (aquatic invertebrates). The report concludes that indirect effects on the aquatic phases of the frog's life history, based on reduction in prey base, are not expected.

\section{Data Gaps}

According to the EPA (U.S. Environmental Protection Agency, 2009a), there are no chronic exposure data on myclobutanil toxicity to freshwater invertebrates. Thus, qualitative assessments made by the EPA are based on similar DMI triazole fungicides, the open literature, and incident data.

Relationship Between Fungicide MOA and Effects in Nonfungal Organisms

As a DMI fungicide that affects a multitude of cytochrome P450 enzymes in mammals, and at least one (CY51) in fungi, cytochrome P450s involved in steroid hormone and xenobiotic metabolism are likely sites of myclobutanil action in aquatic organisms. Physiological repercussions of myclobutanil regulation of these P450s include effects on organism development, reproduction, and ability to metabolize contaminants.

\section{Fenarimol}

Environmental Fate in Aquatic Systems

Due to its relatively high Kow (table 5), fenarimol partitions rapidly into sediments and is likely to be environmentally persistent. Being photolabile, fenarimol is expected to rapidly degrade in “'shallow, clear, well-lit water bodies' but to persist in 'deep, turbid, poorly illuminated water"” (US Environmental Protection Agency, 2007a). It has low potential to bioaccumulate in fish (US Environmental Protection Agency, 2007a).

\section{Mode of Toxic Action in Fungi}

Like myclobutanil, fenarimol [ $\alpha$-(2-chlorophenyl)-(4-chlorophenyl)-5-pyrimidinemethanol] belongs to the sterol DMI fungicides, inhibiting C14-demethylase (CYP51), which is involved in the synthesis of the essential fungal membrane sterol, ergosterol (Griffiths and Howlett, 2002; Fungicide Resistance Action Committee, 2012).

\section{Biochemical Effects in Mammals}

In in vivo studies with rats, a single intraperitoneal dose of fenarimol $(200,000 \mathrm{ug} / \mathrm{kg} / \mathrm{bw})$ affected several cytochrome P450 enzymes, including CYP3A1/2, CYP2E1, CYP2B1, CYP1A1, and CYP1A2 (Paolini and others, 1996). In in vitro studies using human cells (MCF-7) and human placental microsomes, fenarimol has an array of estrogenic, antiestrogenic, and antiandrogenic effects, including inhibition of aromatase (CYP19) (Vinggaard and others, 2000; Andersen and others, 2002) (table 2).

\section{Toxic Effects in Freshwater Organisms}

Fenarimol is moderately to highly toxic to fish and invertebrates (US Environmental Protection Agency, 2007a) (tables 4 and 6) with a variety of biochemical and physiological effects reported (tables 
2 and 3). The endocrine disruptive effects of fenarimol deleteriously affect reproduction and development in both vertebrates and invertebrates (Hassold and Backhaus, 2009). When added to testicular microsomes from carp, fenarimol increased synthesis of ovarian maturation-inducing hormones and inhibited hormone clearance pathways, including glucuronidation of testosterone and estradiol (Thibaut and Porte, 2004). In studies with fathead minnows, a 21-day exposure to fenarimol reduced fecundity (569 $\mu \mathrm{g} / \mathrm{L})$, increased spermatogonia in the testes $(569 \mu \mathrm{g} / \mathrm{L})$, increased oocyte atresia (569 $\mu \mathrm{g} / \mathrm{L}$ ), and altered steroid and vitellogenin levels (96 $\mu \mathrm{g} / \mathrm{L}$ ) (Ankley and others, 2005). Fenarimol significantly inhibits the activity of brain and ovarian aromatase (CYP19) in vitro (Ankley and others, 2005; Hinfray and others, 2006) but has no effect on brain aromatase in vivo (569 $\mu \mathrm{g} / \mathrm{L}$ ) (Ankley and others, 2005). Fenarimol binds the fathead minnow androgen receptor (Ankley and others, 2005). In in vitro studies with several fish species, fenarimol reduced carbonic anhydrase activity, a key regulator of salt- and acid-base balance in fish (Isik and others, 2004; Dogan, 2006).

Fenarimol affects reproduction and development in aquatic invertebrates. A 5-month exposure to fenarimol-induced imposex and reduced fertility or embryo production in the freshwater prosobranch snail, Marisa cornuarietis (EC10 $=0.0186 \mu \mathrm{g} / \mathrm{L}$ ) (Duft and others, 2007). In Daphnia neonates exposed for 21 days, fenarimol reduced fecundity $(\mathrm{EC} 50=377.6 \mu \mathrm{g} / \mathrm{L})$, delayed molting $(\mathrm{EC} 50=430 \mu \mathrm{g} / \mathrm{L})$, and increased the percentage of malformed offspring (EC50=400 $\mu \mathrm{g} / \mathrm{L}$ ), including eye malformations, which may be related to inhibition of ecdysteroid synthesis (Hassold and Backhaus, 2009). At a concentration of $100 \mu \mathrm{M}(33,120 \mu \mathrm{g} / \mathrm{L})$, fenarimol did not affect testosterone metabolism in in vitro microsomal fractions of whole-animal homogenates of the freshwater snail M. cornuarietis or the amphipod, Hyalella azteca, but did significantly increase formation of testosterone metabolites in homogenates of the echinoderm, Paracentrotus lividus (Janer and others, 2005).

Relationship Between Fenarimol Fungal MOA and Effects in Nonfungal Organisms

As for other DMI fungicides, fenarimol inhibition of fungal CYP51 appears predictive of the inhibition of a variety of CYP450s in both vertebrates and invertebrates, disrupting reproduction and development.

\section{Fungicide Resistance Action Committee Mode of Action: Multisite Contact Activity}

\section{Chlorothalonil}

Environmental Fate in Aquatic Systems

The main pathway of chlorothalonil dissipation is via microbial degradation, with degradation rates faster under wet, flooded, or aquatic conditions (U.S. Environmental Protection Agency, 1999; Extension Toxicology Network (EXTOXNET), 2010). Half-lives in water vary from hours to days (Szalkowski and Stallard, 1977; Davies, 1988; Ernst and others, 1991; Caux and others, 1996; State of California, 1999; U.S. Environmental Protection Agency, 1999; Extension Toxicology Network (EXTOXNET), 2010). Concentrations of chlorothalonil and its primary degradate, SDS-3701, are expected to be higher in sediment than in water (U.S. Environmental Protection Agency, 1999). Leaching of the parent compound to groundwater is likely to be low (Krawchuk and Webster, 1987; U.S. Environmental Protection Agency, 1999; Extension Toxicology Network (EXTOXNET), 2010) (table 5).

The bioaccumulation potential of chlorothalonil is low in fish, but in bivalves, chlorothalonil bioconcentration is above the 1000x threshold of concern (U.S. Environmental Protection Agency, 1999, 2007b), making bioconcentration by freshwater mussels of potential concern. While less environmentally persistent than other chlorinated organic compounds (U.S. Environmental Protection 
Agency, 1999), chlorothalonil residues are nonetheless often found in freshwater biota (Caux and others, 1996).

Mode of Toxic Action in Fungi

Chlorothalonil (2,4,5,6-tetrachloro-1,3-benzenedicarbonitrile) has been in use for decades. Due to its multi-site contact-activity MOA (table 1), it is difficult for fungi to develop resistance against chlorothalonil, and it remains among the top five products driving the fungicide market (Troy, 2011). Chlorothalonil exerts its toxic effects through binding to and depletion of glutathione, a nonenzymatic antioxidant critical to the function of several enzymes important in detoxification and cellular respiration (Zhao and others, 2011; Fungicide Resistance Action Committee, 2012).

\section{Biochemical Effects in Mammals}

Chlorothalonil is considered "practically nontoxic" for acute effects to mammals (U.S. Environmental Protection Agency, 1999), but a variety of biochemical and physiological effects have been reported (tables 2 and 3). In rats, it is a renal toxin (175,000 $\mu \mathrm{g} / \mathrm{kg}$ bw/d, from 23 to 29 months) (International Agency for Research on Cancer (IARC), 1999). In a study where nursing rats were treated with VanoxTM (a.i. chlorothalonil) by intraperitoneal injection $(200,00 ; 400,000$; or 800,000 $\mu$ g a.i. $/ \mathrm{kg}$ bw), their offspring exhibited developmental effects and delayed sexual maturation at all doses (Lúcia Scherholz de Castro and Heloísa Chiorato, 2007). Chlorothalonil activated the aryl hydrocarbon receptor (AhR) in human and rat liver cell lines (Long and others, 2003), and induced lipid peroxidation and cytotoxicity, likely via CYP450-mediated metabolism, in isolated rat hepatocytes (Suzuki and others, 2004). Metabolism of chlorothalonil in rats and dogs indicates chlorothalonil binds to glutathione or to cysteine-S-conjugates in the liver (U.S. Environmental Protection Agency, 1999). The EPA lists chlorothalonil as a probable human carcinogen (U.S. Environmental Protection Agency, 1999).

Toxic Effects in Freshwater Organisms

Chlorothalonil is considered very highly toxic to fish and to a range of aquatic invertebrate species (Davies and White, 1985; U.S. Environmental Protection Agency, 2007b) (tables 4 and 6). In contrast, the main degradate (SDS-3701) is only slightly toxic (U.S. Environmental Protection Agency, 2007b).

In fish, sublethal effects of chlorothalonil include altered hatching success and survivability between $3 \mu \mathrm{g} / \mathrm{L}$ (NOEL) and $6.5 \mu \mathrm{g} / \mathrm{L}$ (LOEL) in fathead minnows (U.S. Environmental Protection Agency, 2003), increased respiration in fish at $0.3 \mu \mathrm{g} / \mathrm{L}$ (LOEC), and biased sex ratios and reduced activity in medaka (Oryzias latipes) fry at $0.06 \mu \mathrm{g} / \mathrm{L}$ (Teather and others, 2005).

There is some information on mechanisms by which chlorothalonil may exert its toxic actions in fish and amphibians (table 2). In fish, chlorothalonil exposure lowered hepatic thiol and altered glutathione and glutathione S-transferase (GST) levels (Davies, 1985a; Gallagher and others, 1992; Davies and others, 1994). Chlorothalonil impaired gill function in rainbow trout (Salmo gairdneri) at 2 $\mu \mathrm{g} / \mathrm{L}$ by reducing diffusive capacity (Davies, 1987) and altered immune function as evidenced by altered production of reactive oxygen species (Baier-Anderson and Anderson, 1998, 2000b; Shelley and others, 2009). The altered ability to generate reactive oxygen species (ROS) may occur via chlorothalonil inhibition of NADPH oxidase by binding to its sulfhydryl groups (Baier-Anderson and Anderson, 2000b). Recent work on tadpoles demonstrates that chlorothalonil also has significant effects on corticosterone levels at doses <16.4 $\mu \mathrm{g} / \mathrm{L}$ (McMahon and others, 2011).

The few studies of sublethal effects of chlorothalonil in freshwater invertebrates also report effects on thiol-containing biochemicals and ROS. A 10-day exposure to chlorothalonil increased levels of whole-body GST $(1.8 \mu \mathrm{g} / \mathrm{L})$ and whole-body glutathione $(0.3 \mu \mathrm{g} / \mathrm{L})$ in the crustacean Paratya 
australiensis (Davies and others, 1994), and suppressed ROS production in oyster hemocytes (100 $\mu \mathrm{g} / \mathrm{L}$, in vitro) (Baier-Anderson and Anderson, 2000a). In the latter study, the authors suggest that chlorothalonil may have effects similar to those in fish (inhibition of an NAD[P]H oxidase-like enzyme) and conclude that chlorothalonil is likely to interfere with phagocyte (immune) function in invertebrates.

Bivalves are considered to be at particular risk from chlorothalonil exposure. Water-borne chlorothalonil was highly toxic to glochidia (24h EC50=90 $\mu \mathrm{g} / \mathrm{L}, 48 \mathrm{~h}$ EC50=40 $\mu \mathrm{g} / \mathrm{L}$ ) and juvenile life stages (96h EC50=280 $\mu \mathrm{g} / \mathrm{L}$ ) of freshwater mussels Lampsilis siliquoidea (Bringolf and others, 2007a), Dreissena polymorpha (glochidia 48h EC50=0.97 $\mu \mathrm{g} / \mathrm{L}$ ), and Uno elongates $(48 \mathrm{~h}$ EC50=1,847 $\mu \mathrm{g} / \mathrm{L}$, glochidia) (Faria and others, 2010). Whether chlorothalonil exposure from sediments represents an additional risk to freshwater mussels is unknown (Bringolf and others, 2007a). Sublethal effects of chlorothalonil on freshwater mussels have not been studied; however, oysters are 10 to 40 times more sensitive to chlorothalonil than fish with appreciable ability to bioconcentrate this fungicide (table 5) and are considered representative of freshwater mussels in this regard (U.S. Environmental Protection Agency, 1999). Based on studies in oyster hemocytes, many, if not all, organic pollutants, including fungicides, may be hazardous to bivalve defense systems (Gagnaire and others, 2006).

\section{Relationship Between Chlorothalonil MOA and Effects in Nonfungal Organisms}

The fungal MOA of chlorothalonil appears to be strongly predictive of its effects on nonfungal organisms. In fungi, chlorothalonil exerts its toxic effects through binding to and depleting glutathione, a nonenzymatic antioxidant critical to the function of several enzymes important in detoxification, reactive oxygen production, and cellular respiration. In mammals, fish, and invertebrates, chlorothalonil also affects glutathione and enzymes and processes associated with it.

\section{Summary and Conclusions}

The fungicides covered in this review represent those detected most frequently and (or) at the highest concentrations, with high or increasing use, or have physical and (or) chemical properties indicating they may be persistent in surface waters, making them among the most relevant for closer examination of effects in nontarget organisms. A review of the literature reveals that fungicide mode of toxic action in fungi is sometimes tantalizingly reflective of the biochemical and (or) physiological effects observed in vertebrates and invertebrates; however, far more studies are needed to explore the potential to predict effects based on specific fungicide modes of toxic action. There are very few studies at the ecosystem level, with most examining changes in ecosystem structure and very few examining changes in ecosystem function, arguably a more relevant endpoint. This is especially important given that single species LC50 values (the acute concentration that effects a response in 50 percent of the organisms), used to indicate the lower limit for acute toxicity, appear to dramatically underestimate the toxic potency of some fungicides on ecosystem processes. Mixture studies consistently indicate fungicides have additive, and in some cases synergistic, effects. Synergistic effects are particularly evident with cytochrome P450-demethylase inhibiting fungicides, and studies with additional fungicides are needed. Basic acute- and chronic-toxicity data are missing or inadequate for several fungicides, including boscalid, a recently introduced fungicide that is being found consistently in surface waters across the United States in relatively high concentrations. For fungicides that are particle reactive and persistent in sediments, their effects on freshwater mussels and other freshwater benthic invertebrates are particularly important to determine, as available toxicity studies with pelagic species, mainly Daphnia magna, may not be representative of these benthic species. Finally, there is a critical need for chronic studies of fungicide effects on sublethal endpoints with population- and community-level relevance, such as reproduction, immunocompetence, and ecosystem function. 
The U.S. Environmental Protection Agency pesticide registration process uses existing and new data to ensure each pesticide registered will have no "unreasonable adverse effects on humans, the environment, and nontarget species” (U.S. Environmental Protection Agency, 2012). However, as recognized by the U.S. Environmental Protection Agency registration review process (U.S. Environmental Protection Agency, 2012), the state of the sciences in risk assessment, toxicology, and environmental chemistry continues to evolve. Consequently, there will continue to be new scientific understandings of the active, as well as adjuvant, ingredients in pesticides and their formulations regarding environmental fate and transport, as well as potential biological effects. The compilation summarized in this paper addresses and reveals data gaps in our scientific understanding of the targeted fungicides as potential environmental contaminants. Therefore, information such as this could be useful to the U.S. Environmental Protection Agency and other agencies in registration and registration review activities, as well as for the larger scientific community engaged in new and ongoing research on the potential environmental-health impacts of fungicide use.

\section{References Cited}

Andersen, H.R., Vinggaard, A.M., Rasmussen, T.H., Gjermandsen, I.M., and Cecilie BonefeldJørgensen, Eva, 2002, Effects of currently used pesticides in assays for estrogenicity, androgenicity, and aromatase activity in vitro: Toxicology and Applied Pharmacology, v. 179, p. 1-12.

Andersson, Tommy, Pesonen, Maija, and Johansson, Conny, 1985, Differential induction of cytochrome P-450-dependent monooxygenase, epoxide hydrolase, glutathione transferase, and UDP glucuronyltransferase activities in the liver of the rainbow trout by ß-naphthoflavone or Clophen A50: Biochemical Pharmacology, v. 34, p. 3,309-3,314.

Ankley, G.T., Jensen, K.M., Durhan, E.J., Makynen, E.A., Butterworth, B.C., Kahl, M.D., Villeneuve, D.L., Linnum, Ann, Gray, L.E., Cardon, Mary, and Wilson, V.S., 2005, Effects of two fungicides with multiple modes of action on reproductive endocrine function in the fathead minnow (Pimephales promelas): Toxicological Sciences, v. 86, p. 300-308.

Ankley, G.T., Bencic, D.C., Breen, M.S., Collette, T.W., Conolly, R.B., Denslow, N.D., Edwards, S.W., Ekman, D.R., Garcia-Reyero, Natalia, Jensen, K.M., Lazorchak, J.M., Martinovic, Dalma, Miller, D.H., Perkins, E.J., Orlando, E.F., Villeneuve, D.L., Wang, R.L., and Watanabe, K.H., 2009, Endocrine disrupting chemicals in fish: Developing exposure indicators and predictive models of effects based on mechanism of action: Aquatic Toxicology, v. 92, p. 168-178.

Arvanites, A.C., and Boerth, D.W., 2001, Modeling of the mechanism of nucleophilic aromatic substitution of fungicide chlorothalonil by glutathione: Journal of Molecular Modeling, v. 7, p. 245256.

Aubee, Catherine, and Lieu, David, 2010a, Environmental fate and ecological risk assessment for boscalid new use on rapeseed, including canola (seed treatment): U.S. Environmental Protection Agency, Office of Pesticide Programs, 52 p., accessed August 24, 2012, at http://www.epa.gov/opp00001/chem_search/cleared_reviews/csr_PC-128008_23-Dec-10_a.pdf. Aubee, Catherine, and Lieu, David, 2010b, Environmental fate and ecological risk assessment for boscalid new uses on alfalfa and citrus (group 10): U.S. Environmental Protection Agency, Office of Pesticide Programs,162 p., accessed August 24, 2012, at http://www.epa.gov/opp00001/chem_search/cleared_reviews/csr_PC-128008_19-Feb-10_a.pdf.

Australian Pesticides and Veterinary Medicines Authority, 2010, Advice summary-Application for registration of a chemical product-SIGANEX 600 SC FUNGICIDE - pyrimethanil, 9 p., accessed August 25, 2012, at http://www.apvma.gov.au/advice_summaries/38213.pdf. 
Baier-Anderson, Cal, and Anderson, R.S., 1998, Evaluation of the immunotoxicity of chlorothalonil to striped bass phagocytes following in vitro exposure: Environmental Toxicology and Chemistry, v. 17, p. $1,546-1,551$.

Baier-Anderson, Cal, and Anderson, R.S., 2000a, The effects of chlorothalonil on oyster hemocyte activation - phagocytosis, reduced pyridine nucleotides, and reactive oxygen species production: Environmental Research, v. 83, p. 72-78.

Baier-Anderson, Cal, and Anderson, R.S., 2000b, Suppression of superoxide production by chlorothalonil in striped bass (Morone saxatilus) macrophages-The role of cellular sulfhydryls and oxidative stress: Aquatic Toxicology, v. 50, p. 85-96.

Bartlett, D.W., Clough, J.M., Godwin, J.R., Hall, A.A., Hamer, Mick, and Parr-Dobrzanski, Bob, 2002, The strobilurin fungicides: Pest Management Science, v. 58, p. 649-662.

Beketov, M.A., and Liess, Matthais, 2008, Potential of 11 pesticides to initiate downstream drift of stream macroinvertebrates: Archives of Environmental Contamination and Toxicology, v. 55, p. 247253.

Belden, Jason, McMurry, Scott, Smith, Loren, and Reilley, Paris, 2010, Acute toxicity of fungicide formulations to amphibians at environmentally relevant concentrations: Environmental Toxicology and Chemistry, v. 29, p. 2,477-2,480.

Bjergager, M.B.A., Hanson, M.L., Lissemore, Linda, Henriquez, Nikki, Solomon, K.R., and Cedergreen, Nina, 2011, Synergy in microcosms with environmentally realistic concentrations of prochloraz and esfenvalerate: Aquatic Toxicology, v. 101, p. 412-422.

Bony, Sylvie, Gaillard, Isabelle, and Devaux, Alain, 2010, Genotoxicity assessment of two vineyard pesticides in zebrafish: International Journal of Environmental Analytical Chemistry, v. 90, p. 421428.

Brent, K.J., and Hollomon, D.W., 2007, Fungicide resistance-The assessment of risk: Fungicide Resistance Action Committee Monograph No. 2 (2d revised ed.), p. 1-53, accessed August 23, 2012, at http://www.frac.info/frac/publication/anhang/FRAC_Mono2_2007.pdf

Bringolf, R.B., Cope, W.G., Barnhart, M.C., Mosher, S., Lazaro, P.R., and Shea, Damian, 2007a, Acute and chronic toxicity of pesticide formulations (atrazine, chlorpyrifos, and permethrin) to glochidia and juveniles of Lampsilis siliquoidea: Environmental Toxicology and Chemistry, v. 26, p. 2101-2107.

Bringolf, R.B., Cope, W.G., Eads, C.B., Lazaro, P.R., Barnhart, M.C., and Shea, Damian, 2007b, Acute and chronic toxicity of technical-grade pesticides to glochidia and juveniles of freshwater mussels (Unionidae): Environmental Toxicology and Chemistry, v. 26, p. 2086-2093.

Canistro, Donatella, Pozzetti, Laura, Sapone, Andrea, Broccoli, Marco, Affatato, A.A., Stradiotti, A., Longo, Vincenzo, Menichini, P., Barale, Robero, and Paolini, Moreno, 2008, Perturbation of murine liver cyp-superfamily of isoforms by different combinations of pesticide mixtures: Food Chemical and Toxicology, v. 46, p. 34-42.

Carson, Rachel, 1964, Silent spring: Boston, Houghon Mifflin, 333 p.

Casida, J.E., 2009, Pest toxicology-The primary mechanisms of pesticide action: Chemical Reseach in Toxicology, v. 22, p. 609-619.

Caux, P.Y., Kent, R.A., Fan, G.T., and Stephenson, G.L., 1996, Environmental fate and effects of chlorothalonil - A Canadian perspective: Critical Reviews in Environmental Science and Technology, v. 26, p. 45-93.

Cedergreen, Nina, Kamper, Anja, and Streibig, J.C., 2006, Is prochloraz a potent synergist across aquatic species? A study on bacteria, daphnia, algae and higher plants: Aquatic Toxicology, v. 78, p. 243-252. 
Chen, P.J., Padgett, W.T., Moore, Tanya, Winnik, Witold, Lambert, G.R., Thai, S.F., Hester, S.D., and Nesnow, Stephen, 2009, Three conazoles increase hepatic microsomal retinoic acid metabolism and decrease mouse hepatic retinoic acid levels in vivo: Toxicology and Applied Pharmacology, v. 234, p. 143-155.

Cuffney, T.F., Wallace, J.B., and Webster, J.R., 1984, Pesticide manipulation of a headwater stream invertebrate responses and their significance for ecosystem processes: Freshwater Invertebrate Biology, v. 3, p. 153-171.

Davies, P.E., 1985a, The toxicology and metabolism of chlorothalonil in fish. 3. Metabolism, enzymatics and detoxification in Salmo spp and Galaxias spp.: Aquatic Toxicology, v. 7, p. 277-299.

Davies, P.E., 1985b, The toxicology and metabolism of chlorothalonil in fish. 4. Zinc coexposure and the significance of metallothionein in detoxication in Salmo gairdneri: Aquatic Toxicology, v. 7, p. 301-306.

Davies, P.E., and White, R.W.G., 1985, The toxicology and metabolism of chlorothalonil in fish. 1. Lethal levels for Salmo gairdneri, Galaxias maculatus, Galaxias truttceus and Galaxias auratus and the fate of C14 TCIN in Salmo gairdneri: Aquatic Toxicology, v. 7, p. 93-105.

Davies, P.E., 1987, Physiological, anatomic and behavioral changes in the respiratory system of Salmo gairdneri Rich on acute and chronic exposure to chlorothalonil: Compative Biochemistry and Physiology_Part C Pharmacology, Toxicologogy and Endocrinology, v. 88, p. 113-119.

Davies, P.E., 1988, Disappearance rates of chlorothalonil (TCIN) in the aquatic environment: Bulletin of Environmental Contamination and Toxicology, v. 40, p. 405-409.

Davies, P.E., and Cook, L.S.J., 1993, Catastrophic macroinvertebrate drift and sublethal effects on brown trout, Salmo trutta, caused by cypermethrin spraying on a Tasmanian stream: Aquatic Toxicology, v. 27, p. 201-224.

Davies, P.E., Cook, L.S.J., and Goenarso, D., 1994, Sub-lethal responses to pesticides of several species of australian freshwater fish and crustaceans and rainbow trout: Environmental Toxicology and Chemistry, v. 13, p. 1341-1354.

Dogan, Serap, 2006, The in vitro effects of some pesticides on carbonic anhydrase activity of Oncorhynchus mykiss and Cyprinus carpio carpio fish: Journal of Hazardous Materials, v. 132, p. 171-176.

Ducrot, Virginie, Teixeira-Alves, Mickael, Lopes, Christelle, Delignette-Muller, M.-L., Charles, Sandrine, and Lagadic, Laurent, 2010, Development of partial life-cycle experiments to assess the effects of endocrine disruptors on the freshwater gastropod Lymnaea stagnalis—A case-study with vinclozolin: Ecotoxicology, v. 19, p. 1,312-1,321.

Duft, Martina, Schmitt, Claudia, Bachmann, Jean, Brandelik, Cornelius, Schulte-Oehlmann, Ulrike, and Oehlmann, Joerg, 2007, Prosobranch snails as test organisms for the assessment of endocrine active chemicals - An overview and a guideline proposal for a reproduction test with the freshwater mudsnail Potamopyrgus antipodarum: Ecotoxicology, v. 16, p. 169-182.

Ernst, W.R., Doe, K.G., Jonah, P., Young, J., Julien, G.R.J., and Hennigar, P.A., 1991, The toxicity of chlorothalonil to aquatic fauna and the impact of its operational use on a pond ecosystem: Archives of Environmental Contamination and Toxicology, v. 21, p. 1-9.

European Commission, 2004a, Review report for the active substance pyraclostrobin:Health \& Consumer Protection Directorate-General SANCO/1420/2001-final, 24 p., accessed August 25, 2012, at http://ec.europa.eu/food/plant/protection/evaluation/newactive/pyraclostrobin.pdf.

European Food Safety Authority, 2007, Conclusion regarding the peer review of the pesticide risk assessment of the active substance fludioxinil: European Food Safety Authority Scientific Report 
(2007) 110, 85 p., accessed August 25, 2012, at

http://www.efsa.europa.eu/en/efsajournal/doc/110r.pdf.

Extension Toxicology Network (EXTOXNET), 2010, Pesticide information profile-Chlorothalonil:

Extension Toxicology Network, accessed August 25, 2012, at

http://pmep.cce.cornell.edu/profiles/extoxnet/carbaryl-dicrotophos/chlorothalonil-ext.html\#14.

Faria, Melissa, López, M.A., Fernández-Sanjuan, Maria, Lacorte, Silvia, and Barata, Carlos, 2010,

Comparative toxicity of single and combined mixtures of selected pollutants among larval stages of the native freshwater mussels (Unio elongatulus) and the invasive zebra mussel (Dreissena polymorpha): Science of the Total Environment, v. 408, p. 2,452-2,458.

Friberg-Jensen, Ursula, Nachman, Gosta, and Christoffersen, K.S., 2010, Early signs of lethal effects in Daphnia magna (Branchiopoda, Cladocera) exposed to the insecticide cypermethrin and the fungicide azoxystrobin: Environmental Toxicology and Chemistry, v. 29, p. 2,371-2,378.

Fritz, Rene, Lanen, Catherine, Colas, Virginie, and Leroux, Pierre, 1997, Inhibition of methionine biosynthesis in Botrytis cinerea by the anilinopyrimidine fungicide pyrimethanil: Pesticide Science, $\mathrm{v}$. 49, p. 40-46.

Fungicide Resistance Action Committee, 2012, FRAC code list fungicides sorted by mode of action including FRAC code numbering, accessed August 23, 2012, at http://www.frac.info/frac/index.htm

Gagnaire, Beatrice, Thomas-Guyon, Helene, Burgeot, Thierry, and Renault, Tristan, 2006, Pollutant effects on Pacific oyster, Crassostrea gigas (Thunberg), hemocytes-Screening of 23 molecules using flow cytometry: Cell Biology and Toxicology, v. 22, p. 1-14.

Gallagher, E.P., Canada, A.T., and DiGiulio, R.T., 1992, The protective role of glutathione in chlorothalonil-induced toxicity to channel catfish: Aquatic Toxicology, v. 23, p. 155-168.

Gilliom, R.J., Barbash, J.E., Crawford, C.G., Hamilton, P.A., Martin, J.D., Nakagaki, Naomi, Nowell, L.H., Scott, J.C., Stackelberg, P.E., Thelin, G.P., and Wolock, D.M., 2006, The quality of our Nation's waters-Pesticides in the nation's streams and ground water, 1992-2001: U.S. Geological Survey Circular 1291, 172 p., accessed August 24, 2012, at http://water.usgs.gov/nawqa/pnsp//pubs/circ1291/. Gisi, Ulrich, and Sierotzki, Helge, 2008, Fungicide modes of action and resistance in downy mildews: European Journal of Plant Pathology, v. 122, p. 157-167.

Goetz, A.K., and Dix, D.J., 2009, Mode of action for reproductive and hepatic toxicity inferred from a genomic study of triazole antifungals: Toxicological Sciences, v. 110, p. 449-462.

Griffiths, K.M., and Howlett, B.J., 2002, Transcription of sterol delta(5,6)-desaturase and sterol 14 alpha-demethylase is induced in the plant pathogenic ascomycete, Leptosphaeria maculans, during treatment with a triazole fungicide: FEMS Microbiology Letters, v. 217, p. 81-87.

Gustafsson, Kierstin, Blidberg, Eva, Elfgren, I.K., Hellstrom, Anna, Kylin, Henrik, and Gorokhova, Elena, 2010, Direct and indirect effects of the fungicide azoxystrobin in outdoor brackish water microcosms: Ecotoxicology, v. 19, p. 431-444.

Hassold, Enken, and Backhaus, Thomas, 2009, Chronic toxicity of five structurally diverse demethylase-inhibiting fungicides to the crustacean, Daphnia magna-A comparative assessment: Environmental Toxicology and Chemistry, v. 28, p. 1,218-1,226.

Hata, Masato, Ishii, Yoshikazu, Watanabe, Eri, Uoto, Kouichi, Kobayashi, Shozo, Yoshida, Ken-Ichi, Otani, Tsuyoshi, and Ando, Akikazu, 2010, Inhibition of ergosterol synthesis by novel antifungal compounds targeting C-14 reductase: Medical Mycology, v. 48, p. 613-621.

Hayes, T.B., Collins, Atif, Lee, Melissa, Mendoza, Magdelena, Noriega, Nigel, Stuart, A.A., and Vonk, Aaron, 2002, Hermaphroditic, demasculinized frogs after exposure to the herbicide atrazine at low ecologically relevant doses: Proceedings of the National Academy of Sciences USA, v. 99, p. 5,4765,480 . 
Hinfray, Nathalie , Porcher, J.M., and Brion, Francois, 2006, Inhibition of rainbow trout (Oncorhynchus mykiss) P450 aromatase activities in brain and ovarian microsomes by various environmental substances: Comparative Biochemistry and Physiology, part C, v. 144, p. 252-262.

Hose, G.C., Lim, R.P., Hyne, R.V., and Pablo, Fleur, 2002, A pulse of endosulfan-contaminated sediment affects macroinvertebrates in artificial streams: Ecotoxicology and Environmental Safety, v. 51, p. 44-52.

Hurley, P.M., Hill, R.N., and Whiting, R.J., 1998, Mode of carcinogenic action of pesticides inducing thyroid follicular cell tumors in rodents: Environmental Health Perspectives, v. 106, p. 437-445.

International Agency for Research on Cancer (IARC), 1999, Chlorothalonil: International Agency for Research on Cancer monographs, v. 73, 183 p., accessed August 25, 2012, at http://monographs.iarc.fr/ENG/Monographs/vol73/mono73-11.pdf.

Isik, Semra, Kockar, Feray, Ozensoy, Ozen, and Arslan, Oktay, 2004, Differential in vitro effects of some pesticides on carbonic anhydrase activities from some freshwater and seawater fish erythrocytes: Fresenius Environmental Bulletin, v. 13, p. 25-29.

Jacobsen, P.R., Christiansen, Solfe, Boberg, Julie, Nellemann, Christine, and Hass, Ulla, 2010, Combined exposure to endocrine disrupting pesticides impairs parturition, causes pup mortality and affects sexual differentiation in rats: International Journal of Andrology, v. 33, p. 434-441.

Janer, Gemma, LeBlanc, G.A., and Porte, Cinta, 2005, Androgen metabolism in invertebrates and its modulation by xenoandrogens-A comparative study in Vaudry, H., Roubos, E., Schoofs, L., Fiik, G., Larhammar, D. (eds.), Trends in comparative endocrinology and neurobiology: New York, New York Academy of Sciences, v. 1040, p. 354-356.

Johansson, Markus, Piha, Henna, Kylin, Henrik, and Merilä, Juha, 2006, Toxicity of six pesticides to common frog (Rana temporaria) tadpoles: Environmental Toxicology and Chemistry, v. 25, p. 3,1643,170 .

Judson, R.S., Houck, K.A., Kavlock, R.J., Knudsen, T.B., Martin, M.T., Mortensen, H.M., Reif, D.M., Rotroff, D.M., Shah, Imran, Richard, A.M., and Dix, D.J., 2010, In vitro screening of environmental chemicals for targeted testing prioritization-The ToxCast project: Environmental Health Perspectives, v. 118, p. 485-492.

Kanetis, Loukas, Forster, Helga, Jones, C.A., Borkovich, K.A., and Adaskaveg, J.E., 2008, Characterization of genetic and biochemical mechanisms of fludioxonil and pyrimethanil resistance in field isolates of Penicillium digitatum: Phytopathology, v. 98, p. 205-214.

Kim, J.H., Campbell, B.C., Mahoney, Noreen, Chan, K.L., Molyneux, R.J., and May, G.S., 2007, Enhanced activity of strobilurin and fludioxonil by using berberine and phenolic compounds to target fungal antioxidative stress response: Letters in Applied Microbiology, v. 45, p. 134-141.

Konwick, B.J., Garrison, A.W., Avants, J.K., and Fisk, A.T., 2006, Bioaccumulation and biotransformation of chiral triazole fungicides in rainbow trout (Oncorhynchus mykiss): Aquatic Toxicology, v. 80, p. 372-381.

Krawchuk, B.P., and Webster, G.R.B., 1987, Movement of pesticides to groundwater in an irrigated soil: Water Pollution Research Journal of Canada, v. 22, p. 129-146.

Kreutzweiser, D.P., and Sibley, P.K., 1991, Invertebrate drift in a headwater stream treated with permethrin: Archives of Environmental Contamination and Toxicology, v. 20, p. 330-336.

Laudet, Vincent, 2011, The origins and evolution of vertebrate metamorphosis: Current Biology, v. 21, p. R726-R737.

Leyhe, Jennifer, 2004, Hexazinone analysis of risks to endangered and threatened salmon and steelhead: U.S. Environmental Protection Agency, 28 p., accessed August 26, 2012, at http://www.epa.gov/espp/litstatus/effects/hexazin-analysis.pdf. 
Li, Z.H., Zlabek, Vladmir, Grabic, Roman, Li, Ping, Machova, Jana, Velisek, Josef, and Randak, Tomas, 2010, Effects of exposure to sublethal propiconazole on the antioxidant defense system and Na+-K+ATPase activity in brain of rainbow trout, Oncorhynchus mykiss: Aquatic Toxicology, v. 98, p. 297303.

Long, Manhai, Laier, Peter, Vinggaard, A.M., Andersen, H.R., Lynggaard, Joan, and BonefeldJorgensen, E.C., 2003, Effects of currently used pesticides in the AhR-CALUX assay-Comparison between the human TV101L and the rat H4IIE cell line: Toxicology, v. 194, p. 77-93.

Lúcia Scherholz de Castro, Vera, and Heloísa Chiorato, Selma, 2007, Effects of separate and combined exposure to the pesticides methamidophos and chlorothalonil on the development of suckling rats: International Journal of Hygiene and Environmental Health, v. 210, p. 169-176.

Maltby, Lorraine, Brock, T.C.M., and van den Brink, P.J., 2009, Fungicide risk assessment for aquatic ecosystems - Importance of interspecific variation, toxic mode of action, and exposure regime: Environmental Science and Technology, v. 43, p. 7,556-7,563.

Matthiessen, Peter, 2008, An assessment of endocrine disruption in mollusks and the potential for developing internationally standardized mollusk life cycle test guidelines: Integrated Environmental Assessment and Management, v. 4, p. 274-284.

Mazur, C.S., and Kenneke, J.F., 2008, Cross-species comparison of conazole fungicide metabolites using rat and rainbow trout (Onchorhynchus mykiss) hepatic microsomes and purified human CYP 3A4: Environmental Science and Technology, v. 42, p. 947-954.

McMahon, Taegan, Halstead, Neal, Johnson, Steve, Raffel, T.R., Romansic, J.M., Crumrine, P.W., Boughton, R.K., Martin, L.B., and Rohr, J.R., 2011, The fungicide chlorothalonil is nonlinearly associated with corticosterone levels, immunity, and mortality in amphibians: Environmental Health Perspectives, v. 119, p. 1,098-1,103.

Milling, R.J., and Richardson, C.J., 1995, Mode of action of the anilino-pyrimidine fungicide pyrimethanil.2.Effects on enzyme secretion in Botrytis cinerea: Pesticide Science, v. 45, p. 43-48.

Motoyama, Takayuki, Ohira, Tomohiro, Kadokura, Kaori, Ichiishi, Akihiko, Fujimura, Makoto, Yamaguchi, Isamu, and Kudo, Toshiaki, 2005, An Os-1 family histidine kinase from a filamentous fungus confers fungicide-sensitivity to yeast: Current Genetics, v. 47, p. 298-306.

Muirhead-Thomson, R.C., 1978, Lethal and behavioral impact of chlorpyrifos methyl and temephos on select stream macroinvertebrates: Experimental studies on downstream drift: Archives of Environmental Contamination and Toxicology, v. 7, p. 139-147.

Navarro, V.C., Brozinski, J.M., Leppanen, M.T., Honkanen, J.O., Kronberg, Lief, and Kukkonen, J.V.K., 2011, Inhibition of pyrene biotransformation by piperonyl butoxice and identification of two pyrene derivatives in Lumbriculus variegatus (Oligochaeta): Environmental Toxicology and Chemistry, v. 30, p. 1,069-1,078.

New York State Department of Environmental Conservation, 2005, Pyrimethanil registration of the new active ingredient pyrimethanil, contained in the pesticide product Scala brand SC fungicide 4/05: New York State Department of Environmental Conservation, accessed on August 25, 2012, at http://pmep.cce.cornell.edu/profiles/fung-nemat/febuconazolesulfur/pyrimethanil/pyrimethanil_let_405.html.

Norgaard, K.B., and Cedergreen, Nina, 2010, Pesticide cocktails can interact synergistically on aquatic crustaceans: Environmental Science and Pollution Research, v. 17, p. 957-967.

Ochoa-Acuna, H.G., Bialkowski, Walter, Yale, Gowri, and Hahn, Leighanne, 2009, Toxicity of soybean rust fungicides to freshwater algae and Daphnia magna: Ecotoxicology, v. 18, p. 440-446.

Oesch, Franz, Metzler, M., Fabian, Eric, Kamp, Hennicke, Bernshausen, T., Damm, G., Triebel, S., Döhmer, J., Landsiedel, Robert, and Van Ravenzwaay, Bennard, 2010, In vitro mammalian 
metabolism of the mitosis inhibitor zoxamide and the relationship to its in vitro toxicity: Xenobiotica, v. 40, p. 72-82.

Okubo, T., Yokoyama, Y., Kano, K., Soya, Y., and Kano, I., 2004, Estimation of estrogenic and antiestrogenic activities of selected pesticides by MCF-7 cell proliferation assay: Archives of Environmental Contamination and Toxicology, v. 46, p. 445-453.

Olsvik, P.A., Kroglund, Frode, Finstad, Bengt, and Kristensen, Torstein, 2010, Effects of the fungicide azoxystrobin on Atlantic salmon (Salmo solar L.) smolt: Ecotoxicology and Environmental Safety, v. 73, p. 1852-1861.

Organisation for Economic Cooperation and Development, 2011, Endocrine disruptor testing and assessment: Organisation for Economic Cooperation and Development, accessed on February 6, 2012, at

http://www.oecd.org/document/62/0,2340,en_2649_34377_2348606_1_1_1_1,00.html\#Fish_Sexual_ Development.

Paolini, Moreno, Mesirca, Renata, Pozzetti, Laura, Sapone, Andrea, and Cantelli-Forti, Giorgio, 1996, Molecular non-genetic biomarkers related to fenarimol cocarcinogenesis, organ- and sex-specific CYP induction in rat: Cancer Letters, v. 101, p. 171-178.

Pest Management Regulatory Agency, 2003, Regulatory note on pyraclostrobin, Headline EC and Cabrio EG. REG2003-06: Health Canada, Ottawa Canada, 106 p., accessed August 25, 2012, at http://www.hc-sc.gc.ca/cps-spc/pubs/pest/_decisions/reg2003-06/index-eng.php.

Pest Management Regulatory Agency, 2004, Regulatory note on Boscalid/BAS 510: Ottawa, Canada, Pest Management Regulatory Agency REG2004-02, 118 p., at http://www.hc-sc.gc.ca/cpsspc/pubs/pest/_decisions/reg2004-02/index-eng.php.

Pest Management Regulatory Agency, 2006a, Regulatory note for pyrimethanil: Ottawa, Canada, Pest Management Regulatory Agency REG2006-04, 129 p., accessed on Augustn 25, 2012, at http://www.hc-sc.gc.ca/cps-spc/pubs/pest/_decisions/reg2006-04/index-eng.php.

Pest Management Regulatory Agency, 2006b,--Switch 62.5 WG fungicide (a.i. fludioxonil): Ottawa, Canada, Pest Management Regulatory Agency regulatory note REG2006-08, 101 p., accessed August 25, 2012, at http://publications.gc.ca/collections/Collection/H113-7-2006-8E.pdf.

Pest Management Regulatory Agency, 2007, Regulatory note on azoxystrobin and Dynasty 100FS fungicide: Ottawa, Canada, Pest Management Regulatory Agency REG2007-02, 44 p., accessed August 24, 2012, at http://www.hc-sc.gc.ca/cps-spc/pubs/pest/_decisions/reg2007-02/index-eng.php.

Relyea, R.A., and Hoverman, J.T., 2006, Assessing the ecology in ecotoxicology-A review and synthesis in freshwater systems: Ecology Letters, v. 9, p. 1157-1171.

Rudzok, Susanne, Schmucking, Eike, Graebsch, Carolin, Herbarth, Olf, and Bauer, Mario, 2009, The inducibility of human cytochrome P450 1A by environmental-relevant xenobiotics in the human hepatoma derived cell line HepG2: Environmental Toxicology and Pharmacology, v. 28, p. 370-378. Scribner, E.A., Orlando, J.L., Battaglin, W.A., Sandstrom, M.W., Kuivila, K.M., and Meyer, M.T., 2006, Results of analyses of the fungicide chlorothalonil, its degradation products, and other selected pesticides at 22 surface-water sites in five Southern States, 2003-04: U.S. Geological Survey OpenFile Report 2006-1207, 59 p., accessed August 24, 2012, at http://pubs.usgs.gov/of/2006/1207/.

Shelley, L.K., Balfry, S.K., Ross, P.S., and Kennedy, C.J., 2009, Immunotoxicological effects of a subchronic exposure to selected current-use pesticides in rainbow trout (Oncorhynchus mykiss): Aquatic Toxicology, v. 92, p. 95-103.

Sisman, Turgay, and Turkez, Hasan, 2010, Toxicologic evaluation of imazalil with particular reference to genotoxic and teratogenic potentials: Toxicology and Industrial Health, v. 26, p. 641-648. 
Smalling, K.L., and Orlando, J.L., 2011, Occurrence of pesticides in surface water and sediments from three central California coastal watersheds, 2008-09: U.S. Geological Survey Data Series 600, 70 p., accessed August 24, 2012, at http://pubs.usgs.gov/ds/600/.

State of California, 1999, Hazard assessment of the fungicides benomyl, captan, chlorothalonil, maneb, and ziram to aquatic organisms: Department of Fish and Game Administrative Report 99-1, April 1999, 66 p., accessed August 25, 2012, at http://www.cdpr.ca.gov/docs/emon/surfwtr/hazasm/hazasm99_1.pdf.

Stegeman, J.J., and Hahn, M.E., 1994, Biochemistry and molecular biology of monooxygenases: current perspectives on forms, functions, and regulation of cytochrome P450 in aquatic species, in Malins, D.C., Ostrander, G.K. (eds.), Aquatic toxicology-Molecular, biochemical, and cellular perspectives: Ann Arbor, Mich., Lewis, p. 87-206.

Sun, G.B., Grindstaff, R.D., Thai, S.F., Lambert, G.R., Tully, D.B., Dix, D.J., and Nesnow, Stephen, 2007, Induction of cytochrome P450 enzymes in rat liver by two conazoles, myclobutanil and triadimefon: Xenobiotica, v. 37, p. 180-193.

Suzuki, Toshihide, Nojiri, Hisao, Isono, Hideo, and Ochi, Takafumi, 2004, Oxidative damages in isolated rat hepatocytes treated with the organochlorine fungicides captan, dichlofluanid and chlorothalonil: Toxicology, v. 204, p. 97-107.

Szalkowski, M.B., and Stallard, D.E., 1977, Effect of pH on hydrolysis of chlorothalonil: Journal of Agriculture and Food Chemistry, v. 25, p. 208-210.

Tan, S.W., and Zoeller, R.T., 2007, Integrating basic research on thyroid hormone action into screening and testing programs for thyroid disruptors: Critical Reviews in Toxicology, v. 37, p. 5-10.

Teather, Kevin, Jardine, Carrie, and Gormley, Karen, 2005, Behavioral and sex ratio modification of Japanese medaka (Oryzias latipes) in response to environmentally relevant mixtures of three pesticides: Environmental Toxicology, v. 20, p. 110-117.

Thibaut, Remi, and Porte, Cinta, 2004, Effects of endocrine disrupters on sex steroid synthesis and metabolism pathways in fish: Journal of Steroid Biochemistry, v. 92, p. 485-494.

Toxicology Data Network, 2007, Boscalid: National Institutes of Health, accessed August 24, 2012, at http://toxnet.nlm.nih.gov/cgi-bin/sis/search/a?dbs+hsdb:@term+@DOCNO+7499.

Troy, T.N., 2011, Fast-growing fungicide markets: Farm Chemicals International, accessed February 6, 2012, at http://www.farmchemicalsinternational.com/magazine/?storyid=3238.

University of Hertfordshire, 2012, Pesticide properties database: University of Hertfordshire, accessed August 25, 2012, at http://sitem.herts.ac.uk/aeru/projects/ppdb/index.htm.

U.S. Environmental Protection Agency, 1997, Pesticide Fact Sheet-Azoxystrobin: U.S. Environmental Protection Agency, 23 p., accessed August 24, 2012, at http://nepis.epa.gov/Adobe/PDF/P100BI95.pdf.

U.S. Environmental Protection Agency, 1999, Reregistration eligibility decision (RED) Chlorothalonil: U.S. Environmental Protection Agency EPA-738-R-99-004, 337 p., accessed August 25, 2012, at http://www.epa.gov/oppsrrd1/REDs/0097red.pdf.

U.S. Environmental Protection Agency, 2001, Pesticide Fact Sheet-Zoxamide: U.S. Environmental Protection Agency, 13 p., accessed August 24, 2012, at http://www.epa.gov/pesticides/chem_search/reg_actions/registration/fs_PC-101702_17-May-01.pdf.

U.S. Environmental Protection Agency, 2003, Appendix B, in Chlorothalonil ecological effects characterization: U.S. Environmental Protection Agency, 26 p., accessed August 25, 2012, at http://www.epa.gov/espp/litstatus/effects/redleg-frog/chlorothalonil/appendix-b.pdf.

U.S. Environmental Protection Agency, 2007a, Ecological risk assessment for the fenarimol section 3 use on hops EPA-HQ-OPP-2009-0081-0222: U.S. Environmental Protection Agency, 39 p., accessed 
on August 25, 2012, at http://www.regulations.gov/\#!searchResults;rpp=25;po=0;s=EPA-HQ-OPP2009-0081-0222.

U.S. Environmental Protection Agency, 2007b, Potential risks of labeled chlorothalonil uses to the federally listed California red legged frog (Rana aurora draytonii): U.S. Environmental Protection Agency EPA-HQ-OPP-2009-0081-0096, 140 p., accessed August 25, 2012, at http://www.regulations.gov/\#!documentDetail;D=EPA-HQ-OPP-2009-0081-0096.

U.S. Environmental Protection Agency, 2009a, Appendix K-Risks of myclobutanil use to federally threatened California red-legged frog (Rana aurora draytonii): U.S. Environmental Protection Agency, 9 p., accessed August 25, 2012, at http://www.epa.gov/espp/litstatus/effects/redlegfrog/myclobutanil/appendix-k.pdf.

U.S. Environmental Protection Agency, 2009b, Risks of myclobutanil use to federally threatened California red-legged frog (Rana aurora draytonii): U.S. Environmental Protection Agency EPA-HQOPP-2009-0081-0171, 135 p., accessed August 25, 2012, at http://www.regulations.gov/\#!documentDetail;D=EPA-HQ-OPP-2009-0081-0171.

U.S. Environmental Protection Agency, 2010, Pyrimethanil (CAS Reg. no. 53112-28-0) N-(4,6dimethylpyrimidin-2-yl)aniline (IUPAC) 4,6-dimethyl-N-phenyl-2-pyridineamine (CAS) new uses on small berries (cranberries and bushberries) in the co-formulated end-use product Fluopyram/Pyrimethanil 500 SC: U.S. Environmental Protection Agency EPA-HQ-OPP-2009-00810217, 104 p., accessed August 28, 2012, at http://www.regulations.gov/\#!documentDetail;D=EPAHQ-OPP-2009-0081-0217.

U.S. Environmental Protection Agency, 2011a, Section 3 registration request for uses of zoxamide (chemical \#101702, DP barcodes - D266174 and D254295): U.S. Environmental Protection Agency EPA-HQ-OPP-2009-0081-0212, 123 p., accessed August 24, 2012, at http://www.regulations.gov/\#!documentDetail;D=EPA-HQ-OPP-2009-0081-0212.

U.S. Environmental Protection Agency, 2011b, Ecological risk assessment to support the proposed use of pyraclostrobin on rapeseed (cultivars, varieties, and/or hybrids, including canola and crambe), sweet corn and sugar beet and as an encapsulated production on field forn, pop corn and seed production corn: U.S. Environmental Protection Agency EPA-HQ-OPP-2009-0081-0210, 80 p., at http://www.regulations.gov/\#!documentDetail;D=EPA-HQ-OPP-2009-0081-0210.

U.S. Environmental Protection Agency, 2011c, Registration review: preliminary problem formulation for environmental fate, ecological risk, endangered species, and drinking water exposure assessments for fludioxinil: U.S. Environmental Protection Agency EPA-HQ-OPP-2010-1067-0008, 106 p., accessed August 25, 2012, at http://www.regulations.gov/\#!documentDetail;D=EPA-HQ-OPP-20101067-0008.

U.S. Environmental Protection Agency, 2011d, Fludioxonil final work plan for registration review, December 2011, Case No. 7017: U.S. Environmental Protection Agency EPA-HQ-OPP-2010-1067, 10 p., accessed August 25, 2012, at http://www.regulations.gov/\#!documentDetail;D=EPA-HQ-OPP2010-1067-0010.

U.S. Environmental Protection Agency, 2012, Registering pesticides: U.S. Environmental Protection Agency, accessed August 23, 2012, at http://www.epa.gov/pesticides/regulating/registering/index.htm.

Vetcher, Leandro, Menzella, H.G., Kudo, Toshiaki, Motoyama, Takayuki, and Katz, Leonard, 2007, The antifungal polyketide ambruticin targets the HOG pathway: Antimicrobial Agents and Chemotherapy, v. 51, p. 3,734-3,736.

Vinggaard, A.M., Hnida, C., Breinholt, V.M., and Larsen, J.C., 2000, Screening of selected pesticides for inhibition of CYP19 aromatase activity in vitro: Toxicology in Vitro, v. 14, p. 227-234. 
Wallace, J.B., Lugthart, G.J., Cuffney, T.F., and Schurr, G.A., 1989, The impact of repeated insecticidal treatments on drift and benthos of a headwater stream: Hydrobiologia, v. 179, p. 135-147.

Warming, T.P., Mulderij, Gabi, and Christoffersen, K.S., 2009, Clonal variation in physiological responses of Daphnia magna to the strobilurin fungicide azoxystrobin: Environmental Toxicology and Chemistry, v. 28, p. 374-380.

Young, D.H., and Slawecki, R.A., 2001, Mode of action of zoxamide (RH-7281), a new oomycete fungicide: Pesticide Biochemistry and Physiology, v. 69, p. 100-111.

Young, D.H., Rubio, F.M., and Danis, P.O., 2006, A radioligand binding assay for antitubulin activity in tumor cells: Journal of Biomolecular Screening, v. 11, p. 82-89.

Zhao, H.M., Ruan, H.H., and Li, H.T., 2011, Progress in the research of GSH in cells: Chinese Science Bulletin, v. 56, p. 3057-3063.

Zubrod, J.P., Bundschuh, Mirco, Feckler, Alexander, Englert, Dominic, and Schulz, Ralf, 2011, Ecotoxicological impact of the fungicide tebuconazole on an aquatic decomposer-detritivore system: Environmental Toxicology and Chemistry, v. 30, p. 2718-2724. 


\section{Appendix 1. Qualitative Toxicity Categories}

Table 1-1. Qualitative toxicity categories for fish and aquatic invertebrates.

[LC50, lethal concentration that kills 50 percent of the organisms; EC50, effective

concentration that immobilizes 50 percent of the organisms; table reprinted from Leyhe, 2004]

\begin{tabular}{ll}
\hline \multicolumn{1}{c}{ LC50 or EC50 $(\boldsymbol{\mu g} / \mathbf{L})$} & \multicolumn{1}{c}{ Category } \\
\hline$<100$ & Very highly toxic \\
$100-1,000$ & Highly toxic \\
$>1,000-<10,000$ & Moderately toxic \\
$>10,000-<100,000$ & Slightly toxic \\
$>100,000$ & Practically nontoxic \\
\hline
\end{tabular}

